\section{(A) Check for updates}

Cite this: Polym. Chem., 2018, 9, 2313

\title{
SET-LRP in biphasic mixtures of fluorinated alcohols with water
}

\author{
Adrian Moreno, (DD) a,b Tong Liu, (DD a Liang Ding, ${ }^{a}$ Irene Buzzacchera, ${ }^{\text {a,c,d }}$ \\ Marina Galià, (iD 'b Martin Möller, ${ }^{c}$ Christopher J. Wilson, ${ }^{d}$ Gerard Lligadas (D) a,b and \\ Virgil Percec iD *a
}

\begin{abstract}
Biphasic-binary mixtures of 2,2,2-trifluoroethanol (TFE) or 2,2,3,3-tetrafluoropropanol (TFP) with water were used as reaction media to synthesize well-defined poly(methyl acrylate) (PMA) with chain end functionality close to $100 \%$ by SET-LRP. Non-activated $\mathrm{Cu}(0)$ wire was used as a catalyst, taking advantage of the $\mathrm{Cu}(0)$-activation property that these fluorinated alcohols possess. Biphasic-binary mixtures of water, containing a ligand and $\mathrm{Cu}(\|) \mathrm{Br}_{2}$ either generated by disproportionation of $\mathrm{Cu}(\mathrm{l}) \mathrm{Br}$ or externally added, and an organic solvent, containing a monomer and a polymer, were studied. Two $\mathrm{N}$-ligands were investigated: the classic tris(2-dimethylaminoethyl)amine $\left(\mathrm{Me}_{6}\right.$-TREN) and tris(2-aminoethyl)amine (TREN), as a more economically attractive alternative for technological purposes. The results reported here support the replacement of $\mathrm{Me}_{6}$-TREN by TREN, taking into account the fact that the latter requires small loadings of an externally added $\mathrm{Cu}(\Perp) \mathrm{Br}_{2}$ deactivator and a ligand in the water phase to mediate a living radical polymerization process. Both catalytic systems ensure efficient SET-LRP processes with first order kinetics to high conversion, linear dependence of experimental $M_{n}$ on conversion, narrow molecular weight distribution, and near-quantitative chain end functionality.
\end{abstract}

Received 13th January 2018

Accepted 16th March 2018

DOI: 10.1039/c8py00062j

rsc.li/polymers and branched poly(ethyleneimine) (PEI). ${ }^{2,5,28-31}$ According to the required disproportionation of $\mathrm{Cu}(\mathrm{I}) \mathrm{X}$, the use of solvents that do not mediate sufficient disproportionation (for e.g. acetone and $\mathrm{CH}_{3} \mathrm{CN}$ ) and/or others in which $\mathrm{Cu}(\mathrm{II}) \mathrm{X}_{2}$ is not sufficiently soluble like in the case of toluene, anisole and other non-polar solvents poses a threat to the livingness of the SET-LRP methodology. ${ }^{16,32-34}$

Our laboratory recently developed a library of "programmed" multiphasic SET-LRP systems based on mixtures of organic solvents with water. ${ }^{35-41}$ Previous experiments that inspired this concept will be discussed in a later subchapter. This approach relies on the unexpected immiscibility between a solution of water containing $\mathrm{Cu}(\mathrm{II}) \mathrm{Br}_{2}$ and a ligand with organic solvents, including water miscible organic solvents, containing a monomer and a polymer. Of particular interest are mixtures of organic solvents based on combinations of polar and/or non-polar non-disproportionating solvents with water because they overcome the inherent SET-LRP requirements to use polar disproportionating solvents. To support this statement, we reported relevant examples of SET-LRP synthesis of hydrophobic polymers in biphasic aqueous mixtures of non-polar and polar-non-disproportionation solvents. ${ }^{35-38}$ This approach can also be applied to solvents with good disproportionation capabilities such as alcohols as well as dipolar aprotic solvents (i.e. DMSO, sulfolane, NMP, DMAC and DMF). ${ }^{39-41}$ Most of these systems were developed applying a 
multicomponent catalytic SET-LRP methodology where $\mathrm{Cu}(0)$ is generated "in situ" via the reduction of $\mathrm{Cu}(\mathrm{II}) \mathrm{Br}_{2}$ with $\mathrm{NaBH}_{4}$ although the simplest $\mathrm{Cu}(0)$ wire catalytic system was also successfully employed. ${ }^{5,42,43}$

Recently our laboratory reported the replacement of $\mathrm{Me}_{6}$-TREN, the common ligand in the first generation of "programmed" multiphasic SET-LRP systems, by TREN, which is 80 times less expensive. ${ }^{40}$ This attractive alternative provided excellent results when applied to the aqueous polymerization of vinyl chloride $\mathrm{e}^{44-46}$ and also to the $\mathrm{Cu}(0)$-catalyzed SET-LRP in organic media. ${ }^{1,47}$ Biphasic-binary water-organic solvent mixtures containing traditional disproportionating and nondisproportionating organic solvents were reinvestigated using TREN and non-activated $\mathrm{Cu}(0)$ wire to further reduce the cost of these "programmed" biphasic SET-LRP systems for largescale applications. The work reported in this manuscript expands the scope of this biphasic SET-LRP methodology to mixtures of 2,2,2-trifluoroethanol (TFE) and 2,2,3,3-tetrafluoropropanol (TFP) with water. These fluorinated alcohols carry both fluorinated hydrophobic and hydroxyl hydrophilic sites, which help to mediate the disproportionation of $\mathrm{Cu}(\mathrm{I}) \mathrm{X}$, solubilize monomers and polymers with a wide polarity range, and consequently have the potential to serve as "universal solvents" for the SET-LRP of a larger diversity of monomers than any other solvent used before., ${ }^{2,4,5,8}$ These fluorinated alcohols facilitated efficient SET-LRP to prepare near-perfect chain-end functional hydrophilic, hydrophobic, amphiphilic and also semifluorinated acrylates ${ }^{20,21,27}$ and methacrylates. ${ }^{22,23}$ Moreover, they possess a self-activation property by which commercial $\mathrm{Cu}(0)$ wire used as a catalyst for SET-LRP is activated in situ. ${ }^{24}$ This avoids pre-activation treatments, ${ }^{48,49}$ with reducing agents or acids, to remove the oxide layer on the surface of commercial wires and paves the way to practice SET-LRP without undesirable induction periods. ${ }^{5}$

\section{Results and discussion}

\section{Previous experiments that inspired "programmed" biphasic SET-LRP systems}

The scope of polymers and macromolecular architectures accessible by SET-LRP was originally thought to be determined by the solubility of the targeted monomers and polymers in solvents with good disproportionating properties. However, it has to be noted that a certain homogeneous SET-LRP process even succeeded when transitioned to biphasic systems due to the precipitation of the polymer out of the reaction mixture beyond a certain degree of polymerization. This was first observed and reported by our laboratory during the synthesis of ultrahigh molar mass poly(methyl acrylate) (PMA) by the $\mathrm{Cu}(0)$ powder-catalyzed SET-LRP of methyl acrylate (MA) in DMSO. ${ }^{1}$ Our laboratory also reported the formation of a biphasic system for the SET-LRP of butyl acrylate (BA) in DMSO. ${ }^{14}$ Later, the $\mathrm{Cu}(0)$ wire-catalyzed SET-LRP of challenging long hydrocarbon chain hydrophobic monomers such as lauryl acrylate and stearyl acrylate in DMSO and isopropanol also furnished "self-generated" biphasic systems. ${ }^{50}$ Moreover, the "self-generated" system during the SET-LRP of BA in DMSO was investigated in more detail by the laboratory of Haddleton that reported appealing advantages in terms of enhanced endgroup fidelity via suppression of bimolecular termination and in situ purification of the resulting polymer from copper species. ${ }^{8,51-53}$ The SET-LRP of BA also resulted in biphasic systems when dimethyl lactamide was used as a solvent. $^{54}$ Meanwhile, a biphasic reaction mixture containing $\mathrm{Cu}(\mathrm{II}) \mathrm{Br}_{2}$ solution in alcohol separated from the immiscible polymer solution in alcohol was observed during the SET-LRP of 2-ethylhexyl acrylate in TFE. ${ }^{20}$ These developments together with the development of SET-LRP of $N$-isopropylacrylamide catalyzed by $\mathrm{Cu}(0)$ generated in situ by the reduction of $\mathrm{Cu}(\mathrm{II}) \mathrm{Br}_{2}$ with $\mathrm{NaBH}_{4}$ in water led to the elaboration of "programmed" biphasic SET-LRP systems that are produced by design. ${ }^{42,43}$

\section{SET-LRP of MA catalyzed by non-activated $\mathrm{Cu}(0)$ wire $/ \mathrm{Me}_{6}^{-}$ TREN in TFE/water and TFP/water mixtures}

Previously, we reported the SET-LRP of MA and BA, using $\mathrm{Cu}(0)$ generated in situ by the reduction of $\mathrm{Cu}(\mathrm{II}) \mathrm{Br}_{2}$ with $\mathrm{NaBH}_{4}$, in "programmed" bi(multi)phasic alcohol/water mixtures. ${ }^{35,41}$ The selection of an alcohol solvent was determinant for the evolution of the SET-LRP reaction mixture. Whereas systems based on higher alcohols remained biphasic up to complete conversion, compositions based on methanol and ethanol transitioned, above a certain conversion and molecular weight, to a triphasic system. Other "programmed" biphasic SET-LRP systems based on both disproportionating and non-disproportionating solvents were also successfully developed using a more convenient methodology based on $\mathrm{Cu}(0)$ wire. ${ }^{36,39,40}$ The driving force of these "programmed" bi(multiphasic) SET-LRP systems is the immiscibility of water containing $\mathrm{Cu}(\mathrm{II}) \mathrm{Br}_{2}$ and the ligand with even water-soluble solvents containing the monomer and polymer. This effect has dramatic implications even in the presence of traces of water.

However, neither of these catalytic systems has ever been used to study in detail mixtures of water with one of the most versatile classes of SET-LRP solvents such as TFE and TFP. Hence, the first series of experiments reported here focus on the $\mathrm{Me}_{6}$-TREN-mediated SET-LRP of MA in mixtures of these fluorinated alcohols with water in the presence of non-activated $\mathrm{Cu}(0)$ wire (Scheme 1a). A series of kinetic experiments were performed in various alcohol/water ratios using the monofunctional initiator methyl 2-bromopropionate (MBP) under the following conditions $[\mathrm{MA}]_{0} /[\mathrm{MBP}]_{0} /\left[\mathrm{Me}_{6}-\mathrm{TREN}_{0}=\right.$ 222/1/0.1. Fig. 1 and 2 show all the kinetic experiments while more relevant data from these experiments are summarized in Table 1 . These experiments were performed under conditions comparable to those reported under homogeneous conditions in TFE and TFP. ${ }^{20-24}$ When biphasic mixtures of TFE and TFP with water were employed, the ratio between TFE and TFP to water was varied from $9 / 1$ to $8 / 2$ and to $7 / 3$ (Fig. 1, 2 and Table 1) in order to maintain comparable conditions with similar experiments performed with acetone/water ${ }^{36}$ aceto- 
a)

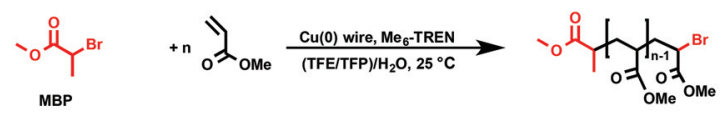

b)

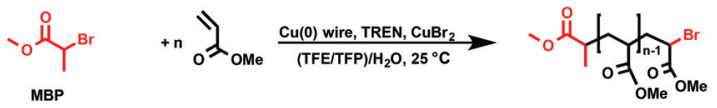

c)

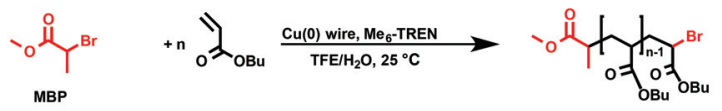

d)
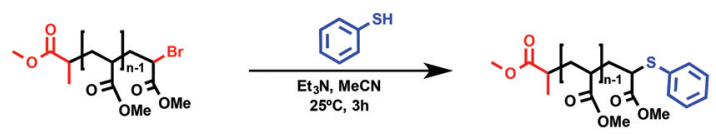

Scheme 1 (a) $\mathrm{Me}_{6}$-TREN and (b) TREN-mediated SET-LRP of MA in binary mixtures of TFE or TFP with water in the presence of non-activated $\mathrm{Cu}(0)$ wire. (c) $\mathrm{Me}_{6}$-TREN-mediated SET-LRP of BA in binary mixtures of TFE with water in the presence of non-activated $\mathrm{Cu}(0)$ wire. (d) "thio-bromo click" modification of the corresponding PMA with thiophenol.

nitrile/water ${ }^{38}$ and alcohols/water, ${ }^{41}$ although a similar trend of the rate of reaction was observed up to solvent/water $=6 / 4$, $\mathrm{v} / \mathrm{v}^{36,38,41}$ At lower ratios between solvent and water corresponding to less solvent in the reaction mixture the concentration of the solvent becomes too low to maintain a biphasic system $^{41}$ and the mechanism of SET-LRP changes from biphasic to triphasic. The second part of this mechanism will be investigated and be reported in different publications.

The first two experiments were performed in pure TFE and TFP for comparison purposes (Fig. 1a and 2a, respectively). As described previously, ${ }^{20-24,27}$ both fluorinated alcohols behaved excellently as SET-LRP solvents in the non-activated $\mathrm{Cu}(0)$ wire/ $\mathrm{Me}_{6}$-TREN-mediated polymerization of MA. The living behavior of these polymerizations was validated through the linear evolution of $\ln \left([\mathrm{M}]_{0} /[\mathrm{M}]\right)$ vs. polymerization time, narrow dispersity and almost quantitative chain end functionality. Note that no significant differences in terms of $k_{\mathrm{p}}^{\text {app }}$ and molecular weight control were observed between the polymerizations carried out in these two alcohols. In both cases $k_{\mathrm{p}}^{\mathrm{app}}$ was almost $0.015 \mathrm{~min}^{-1}, I_{\text {eff }}$ was close to $100 \%$, and $M_{\mathrm{w}} / M_{\mathrm{n}}$ at the end of the polymerization reached values $<1.15$ in all systems (Table 1, entries 1 and 5).

It is important to point out that SET-LRP of MA in both fluorinated alcohols proceeds in a one phase through the entire reaction, resulting in a clear, homogeneous and transparent reaction mixture at high conversion (Fig. 3a and e). Next experiments were carried out in mixtures of TFE and TFP containing $10 \%, 20 \%$ and $30 \%$ water (Fig. $1 \mathrm{~b}-\mathrm{d}$ and $2 \mathrm{~b}-\mathrm{d}$, respectively). All kinetic experiments showed high reproducibility and accomplish the expected features of a living polymerization system. This statement is supported by first order kinetic experiments showing also experimental $M_{\mathrm{n}}$ increasing linearly with conversion, regardless of the alcohol/water ratio. Table 1 entries 2-4 and 6-8 collect the more relevant data obtained from these experiments. Remarkably, $k_{\mathrm{p}}^{\text {app }}$ increases continuously with the water content. The highest $k_{\mathrm{p}}^{\mathrm{app}}$ was observed at an alcohol/water volume ratio $7 / 3\left(k_{\mathrm{p}}^{\text {app }}=\right.$ $0.028 \mathrm{~min}^{-1}$ in TFE/water and $0.040 \mathrm{~min}^{-1}$ in TFP/water). The addition of only $10 \%$ water to TFE increased the rate constant from $k_{\mathrm{p}}^{\mathrm{app}}=0.013 \mathrm{~min}^{-1}$ to $k_{\mathrm{p}}^{\mathrm{app}}=0.019 \mathrm{~min}^{-1}$ (compare Fig. $1 \mathrm{a}$ with $\mathrm{b}$ and Table 1 entries 1 and 2). The increment of $k_{\mathrm{p}}^{\text {app }}$ continues up to the mixture containing $30 \%$ water. Thus, in the a)

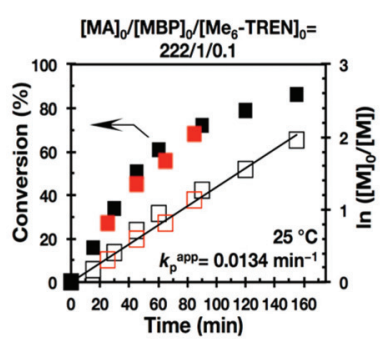

c)

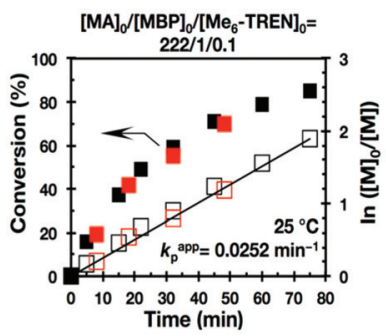

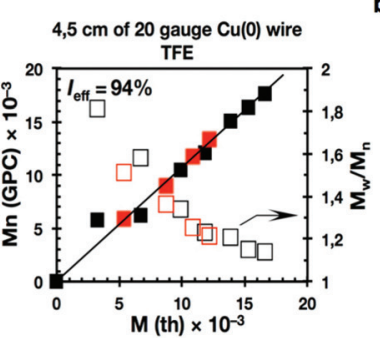

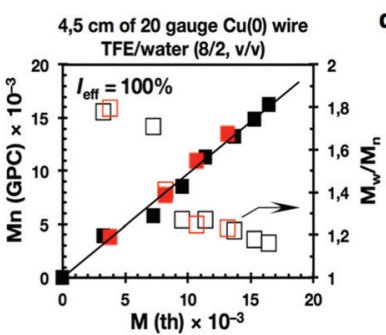

b)

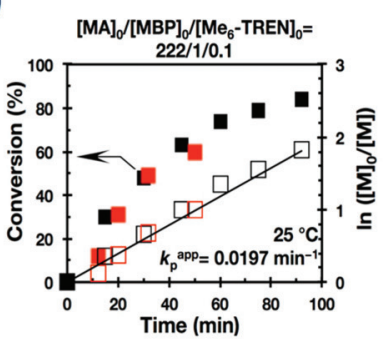

d)

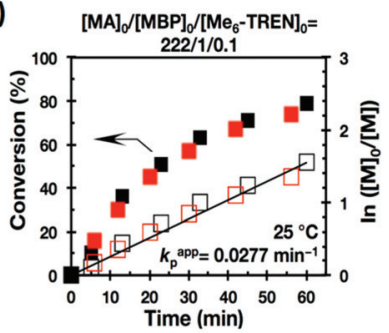

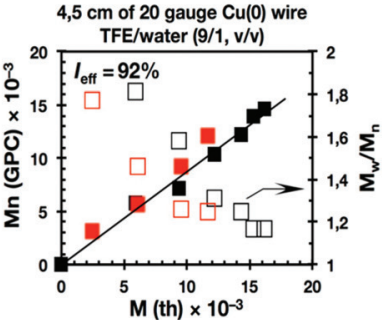

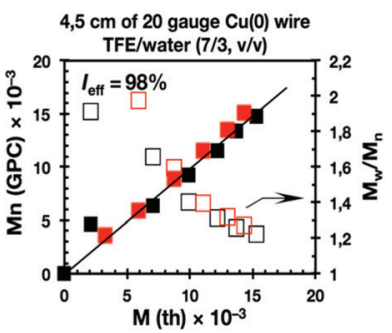

Fig. 1 Kinetic plots, molecular weight and dispersity evolution for the SET-LRP of MA in TFE and TFE/water mixtures initiated with MBP and catalyzed by nonactivated $\mathrm{Cu}(0)$ wire at $25^{\circ} \mathrm{C}$. (a) TFE; (b) TFE/water $(9 / 1, \mathrm{v} / \mathrm{v})$; (c) TFE/water $(8 / 2, \mathrm{v} / \mathrm{v})$ and (d) TFE/water (7/3, v/v). The v/v ratio must be multiplied by 10 to obtain \% solvent/\% water. The value of $v+v$ must be divided by 10 to obtain the total volume of solvents, $1 \mathrm{~mL}$. Reaction conditions: $\mathrm{MA}=1 \mathrm{~mL}$, (a) TFE $=0.5 \mathrm{~mL}$, (b, c, d) TFE + water $=0.5 \mathrm{~mL},[\mathrm{MA}]_{0} /[\mathrm{MBP}]_{0} /\left[\mathrm{Me}_{6}-\mathrm{TREN}\right]_{0}=222 / 1 / 0.1$. Experimental data in different colors were obtained from different kinetic experiments sometimes performed by different researchers. 
a)

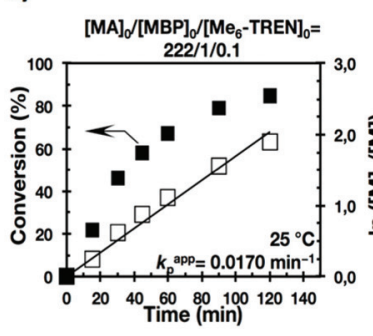

c) $[\mathrm{MA}]_{0} /[\mathrm{MBP}]_{0} /\left[\mathrm{Me}_{6}-\mathrm{TREN}\right]_{0}=$

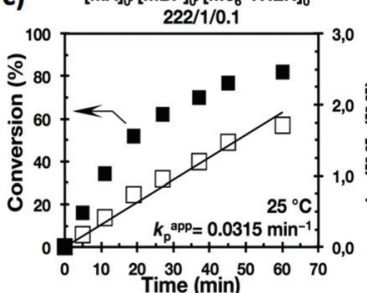

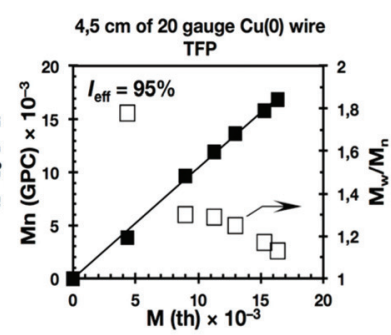

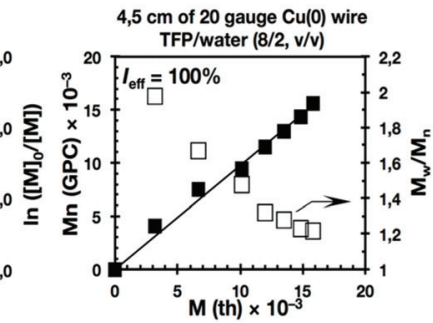

b)
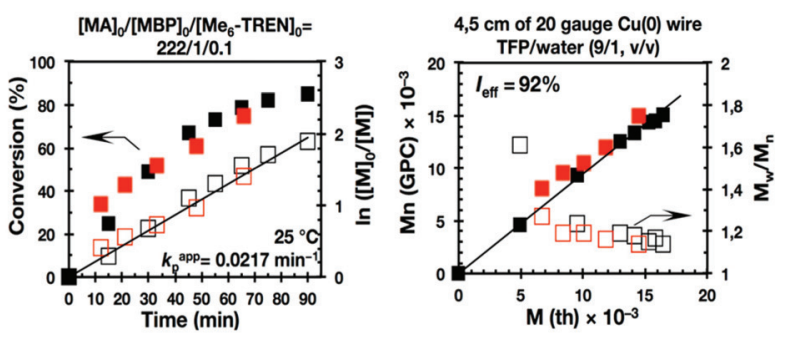

d) $[\mathrm{MA}]_{0} /[\mathrm{MBP}]_{0} /\left[\mathrm{Me}_{6}-\mathrm{TREN}_{0}=\right.$

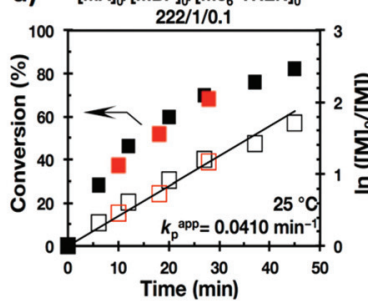

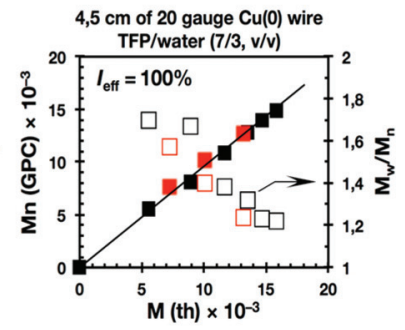

Fig. 2 Kinetic plots, molecular weight and dispersity evolution for the SET-LRP of MA in TFP and TFP/water mixtures initiated with MBP and catalyzed by nonactivated $\mathrm{Cu}(0)$ wire at $25^{\circ} \mathrm{C}$. (a) TFP; (b) TFP/water $(9 / 1, \mathrm{v} / \mathrm{v})$; (c) TFP/water $(8 / 2, \mathrm{v} / \mathrm{v}$ ) and (d) TFP/water $(7 / 3$, v/v). The v/v ratio must be multiplied by 10 to obtain \% solvent/\% water. The value of $v+v$ must be divided by 10 to obtain the total volume of solvents, $1 \mathrm{~mL}$. Reaction conditions: $\mathrm{MA}=1 \mathrm{~mL}$, (a) TFP $=0.5 \mathrm{~mL}$, (b, c, d) TFE + water $=0.5 \mathrm{~mL},[\mathrm{MA}]_{0} /[\mathrm{MBP}]_{0} /\left[\mathrm{Me}_{6}-\mathrm{TREN}\right]_{0}=222 / 1 / 0.1$. Experimental data in different colors were obtained from different kinetic experiments sometimes performed by different researchers.

Table 1 SET-LRP of MA in biphasic mixtures of water with 2,2,2-trifluoroethanol (TFE) and 2,2,3,3-tetrafluoro-1-propanol (TFP) mediated with Me ${ }^{-}$ TREN and catalyzed by nonactivated $4.5 \mathrm{~cm}$ of 20 gauge $\mathrm{Cu}(0)$ wire. Reaction conditions: Monomer $=1 \mathrm{~mL}$; solvent + water $=0.5 \mathrm{ml}$. The v/v ratio must be multiplied by 10 to obtain \% solvent/\% water. The value of $v+v$ must be divided by 20 to obtain the total volume of solvents, $0.5 \mathrm{~mL}$

\begin{tabular}{|c|c|c|c|c|c|c|c|c|c|}
\hline Entry & Reaction medium & Reaction conditions & & $k_{\mathrm{p}}^{\mathrm{app}}\left(\min ^{-1}\right)$ & $k_{\mathrm{p}(\mathrm{s}+\mathrm{w})}^{\mathrm{app}} / k_{\mathrm{p}(\mathrm{s})}^{\mathrm{app}}$ & $\begin{array}{l}\text { Reaction } \\
\text { time }^{a}(\mathrm{~min})\end{array}$ & $\begin{array}{l}\text { Conv. } \\
(\%)\end{array}$ & $\left(M_{\mathrm{w}} / M_{\mathrm{n}}\right)$ & $\begin{array}{l}I_{\text {eff }}^{b} \\
(\%)\end{array}$ \\
\hline 1 & TFE & {$[\mathrm{MA}] /[\mathrm{MBP}] /\left[\mathrm{Me}_{6}{ }^{-\mathrm{TREN}}\right.$} & ] $222 / 1 / 0.1$ & 0.013 & - & 155 & 86 & 1.14 & 94 \\
\hline 4 & $\mathrm{TFE} / \mathrm{H}_{2} \mathrm{O}(7 / 3, \mathrm{v} / \mathrm{v})$ & {$[\mathrm{MA}] /[\mathrm{MBP}] /\left[\mathrm{Me}_{6}-\mathrm{TREN}\right.$} & $222 / 1 / 0.1$ & 0.028 & 2.15 & 60 & 79 & 1.22 & 98 \\
\hline 5 & TFP & {$[\mathrm{MA}] /[\mathrm{MBP}] /\left[\mathrm{Me}_{6}-\mathrm{TREN}\right.$} & ] $222 / 1 / 0.1$ & 0.017 & - & 120 & 85 & 1.13 & 95 \\
\hline 8 & $\mathrm{TFP} / \mathrm{H}_{2} \mathrm{O}(7 / 3, \mathrm{v} / \mathrm{v})$ & {$[\mathrm{MA}] /[\mathrm{MBP}] /\left[\mathrm{Me}_{6}-\mathrm{TREN}\right.$} & $222 / 1 / 0.1$ & 0.040 & 2.35 & 45 & 82 & 1.22 & 100 \\
\hline 9 & TFE & {$[\mathrm{BA}] /[\mathrm{MBP}] /\left[\mathrm{Me}_{6}-\mathrm{TREN}\right]$} & $222 / 1 / 0.1$ & 0.006 & - & 330 & 84 & 1.15 & 100 \\
\hline 10 & $\mathrm{TFE} / \mathrm{H}_{2} \mathrm{O}(9 / 1, \mathrm{v} / \mathrm{v})$ & {$[\mathrm{BA}] /[\mathrm{MBP}] /\left[\mathrm{Me}_{6}-\mathrm{TREN}\right]$} & $222 / 1 / 0.1$ & 0.015 & 2.50 & 120 & 82 & 1.18 & 100 \\
\hline 11 & $\mathrm{TFE} / \mathrm{H}_{2} \mathrm{O}(8 / 2, \mathrm{v} / \mathrm{v})$ & {$[\mathrm{BA}] /[\mathrm{MBP}] /\left[\mathrm{Me}_{6}-\mathrm{TREN}\right]$} & $222 / 1 / 0.1$ & 0.020 & 3.33 & 90 & 82 & 1.20 & 100 \\
\hline 12 & $\mathrm{TFE} / \mathrm{H}_{2} \mathrm{O}(7 / 3, \mathrm{v} / \mathrm{v})$ & {$[\mathrm{BA}] /[\mathrm{MBP}] /\left[\mathrm{Me}_{6}-\mathrm{TREN}\right]$} & $222 / 1 / 0.1$ & 0.028 & 4.66 & 65 & 83 & 1.17 & 100 \\
\hline
\end{tabular}

${ }^{a}$ The reaction time to the monomer conversion (\%) is reported in the next column. ${ }^{b}$ Initiator efficiency.

presence of $20 \%$ water $k_{\mathrm{p}}^{\mathrm{app}}$ increases to $0.025 \mathrm{~min}^{-1}$ whereas in TFE containing $30 \%$ water the rate constant increases by a factor of 2.15 in comparison to the experiment carried out in pure TFE $\left(k_{\mathrm{p}}^{\mathrm{app}}=0.013 \mathrm{~min}^{-1}\right.$ in pure TFE to $k_{\mathrm{p}}^{\text {app }}=0.019 \mathrm{~min}^{-1}$ in $\mathrm{TFE} /$ water $7 / 3, \mathrm{v} / \mathrm{v}$ ). The same trend was observed for the homologous TFP/water mixtures (compare Table 1, entries $5-8)$. As can be seen in Fig. $4 \mathrm{a}$ and $\mathrm{b}, k_{\mathrm{p}}^{\mathrm{app}}$ increases linearly as the volume fraction of water $\left(\Phi_{\mathrm{H}_{2} \mathrm{O}}\right)$ increases in both fluorinated alcohol/water mixtures. Butyl acrylate (BA) was used to expand the monomer scope of these biphasic SET-LRP systems to more hydrophobic monomers (Fig. 5). The polymerization of BA was investigated in various TFE/water mixtures (Table 1 entries 9-12). As can be seen in Fig. 3, the polymerization of BA follows the expected characteristics of a living polymerization reaction. In this case, $k_{\mathrm{p}}^{\mathrm{app}}$ also increases linearly as the volume fraction of water $\left(\Phi_{\mathrm{H}_{2} \mathrm{O}}\right)$ increases (Fig. 4c).

The biphasic nature of the TFE/water and TFP/water systems is supported by the series of digital images shown in Fig. $3 \mathrm{~b}-\mathrm{d}$ and $\mathrm{f}-\mathrm{h}$, respectively. At the transition from pure alcohol to the system containing $10 \%$ water the reaction mixture became slightly turbid in both TFE and TFP (Fig. 3b and $\mathrm{f}$ ) rather than transparent (Fig. 3a and e). This turbidity 


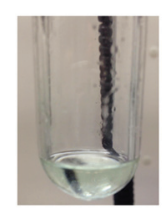

TFE

e)

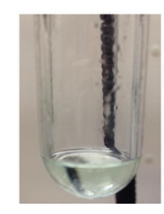

TFP b)

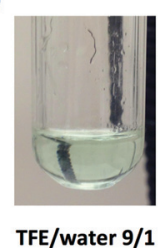

f)

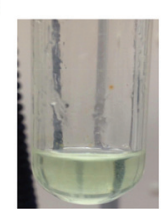

TFP/water 9/1 c)

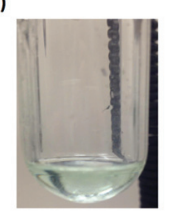

TFE/water 8/2

g)

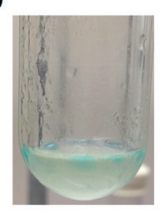

TFP/water $8 / 2$ d)

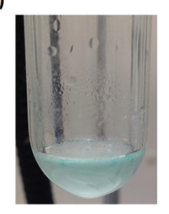

TFE/water $7 / 3$

h)

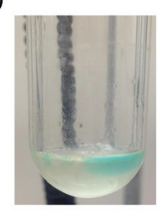

TFP/water $7 / 3$
Fig. 3 Visualization of the reaction mixture after SET-LRP of MA initiated with $\mathrm{MBP}$ and catalyzed by non-activated $\mathrm{Cu}(0)$ wire at $25^{\circ} \mathrm{C}$ in (a) TFE; (b) TFE/water (9/1, v/v); (c) TFE/water (8/2, v/v); (d) TFE/water (7/ 3, v/v); (e) TFP; (f) TFP/water (9/1, v/v); (g) TFP/water $(8 / 2, \mathrm{v} / \mathrm{v})$ and (h) TFP/water $(7 / 3, v / v)$. Reaction conditions: $M A=1 \mathrm{~mL}$, fluorinated solvent $(\mathrm{TFE} / \mathrm{TFP})+$ water $=0.5 \mathrm{~mL},[\mathrm{MA}]_{0} /[\mathrm{MBP}]_{0} /\left[\mathrm{Me}_{6}-\mathrm{TREN}\right]_{0}=222 / 1 / 0.1$. was more evident at a ratio $8 / 2 \mathrm{v} / \mathrm{v}$, especially in the TFP/water system. The system at $8 / 2, \mathrm{v} / \mathrm{v}$ shows some bluish water droplets, containing mainly $\mathrm{Cu}(\mathrm{II}) \mathrm{Br}_{2} / \mathrm{Me}_{6}$-TREN complexes and probably some traces of TFP and monomer, which are not miscible with the organic phase containing TFP, PMA and the residual MA. As can be seen in Fig. $3 \mathrm{~d}$ and $\mathrm{h}$, a clear biphasic system evolved in both systems at $\Phi_{\mathrm{H}_{2} \mathrm{O}}=0.3$. It is remarkable that the transition from one phase to the biphasic system did provide only a small increase in $M_{\mathrm{w}} / M_{\mathrm{n}}$ from $\sim 1.15$ to $\sim 1.20$ and did not affect the $I_{\text {eff }}$ (Table 1). Representative gel permeation chromatography (GPC) traces of PMA obtained during the SET-LRP process TFE/water at a ratio $8 / 2, \mathrm{v} / \mathrm{v}$ as a function of conversion are shown in Fig. 6a.

\section{SET-LRP of MA catalyzed by non-activated $\mathrm{Cu}(0)$ wire/TREN/ $\mathrm{Cu}(\mathrm{II}) \mathrm{Br}_{2}$ in $\mathrm{TFE} /$ water and $\mathrm{TFP} /$ water mixtures}

Recently our laboratory reported the replacement of $\mathrm{Me}_{6^{-}}$ TREN, the common ligand in the first generation of "programmed" multiphasic SET-LRP systems, by TREN, ${ }^{40}$ which is a)

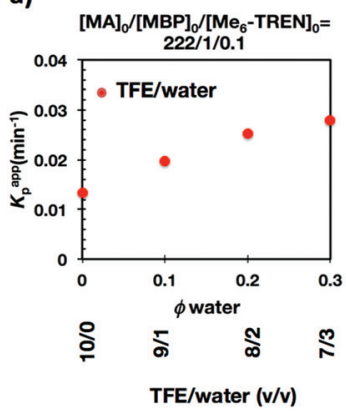

b)

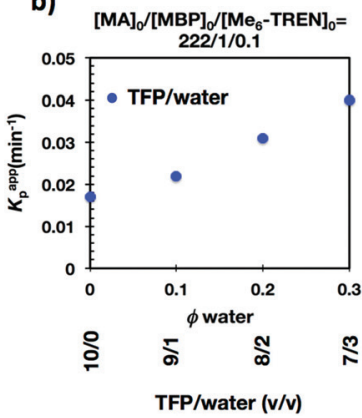

c)

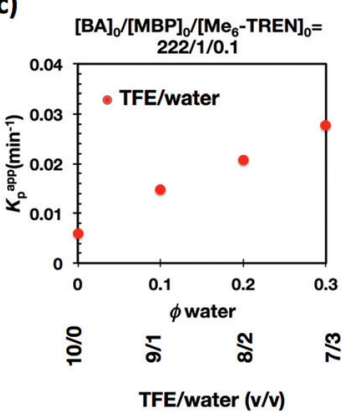

Fig. 4 The dependence of $k_{\mathrm{p}}^{\text {app }}$ with the volume fraction of water $\left(\Phi_{\mathrm{H}_{2} \mathrm{O}}\right)$ on the SET-LRP of MA and BA initiated with MBP mediated by Me ${ }_{6}$-TREN and catalyzed by $4.5 \mathrm{~cm}$ of non-activated $\mathrm{Cu}(0)$ wire in ( $\mathrm{a}$ and $\mathrm{c}$ ) TFE/water and (b) TFP/water mixtures.

a)

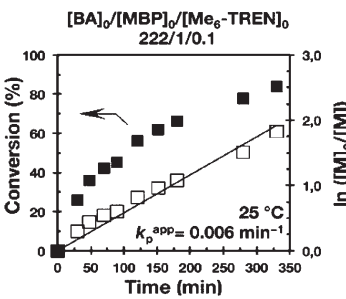

c)

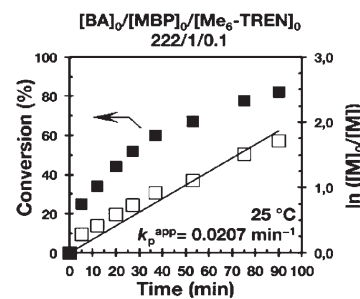

$4.5 \mathrm{~cm}$ of 20 gauge $\mathrm{Cu}(0)$ wire
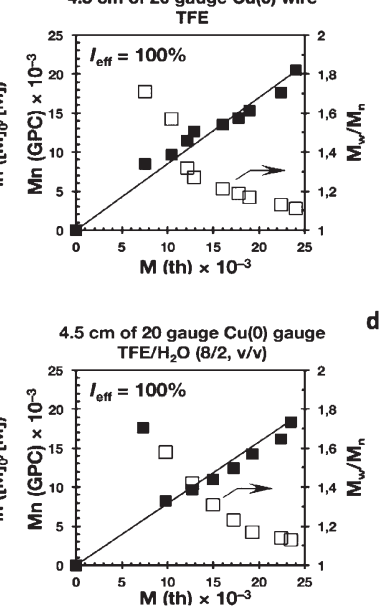
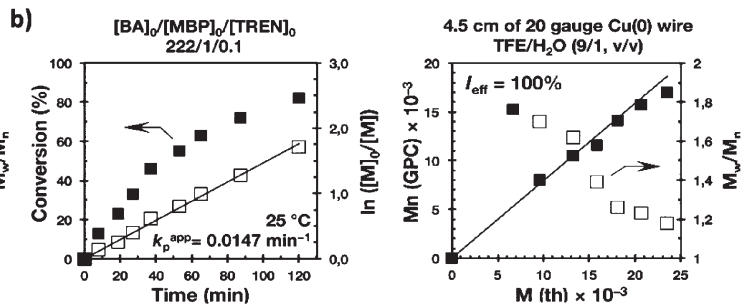

d)

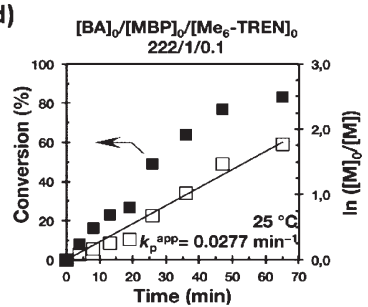

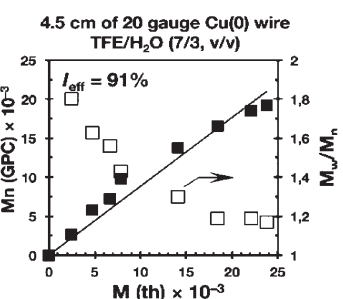

Fig. 5 Kinetic plots, molecular weight and dispersity evolution for the SET-LRP of BA in TFE and TFE/water mixtures initiated with MBP and catalyzed by non-activated $\mathrm{Cu}(0)$ wire at $25^{\circ} \mathrm{C}$. (a) TFE; (b) TFE/water (9/1, v/v); (c) TFE/water (8/2, v/v) and (d) TFE/water (7/3, v/v). The v/v ratio must be multiplied by 10 to obtain \% solvent/\% water. The value of $v+v$ must be divided by 10 to obtain the total volume of solvents, $1 \mathrm{~mL}$. Reaction conditions: $\mathrm{MA}=1 \mathrm{~mL}$, (a) TFE $=0.5 \mathrm{~mL}$, (b, c, d) TFE + water $=0.5 \mathrm{~mL},[B]_{0} /[\mathrm{MBP}]_{0} /\left[\mathrm{Me}_{6}-\mathrm{TREN}\right]_{0}=222 / 1 / 0.1$. 
a)

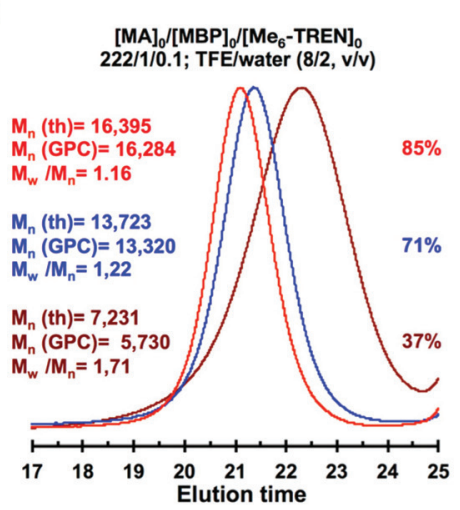

b)

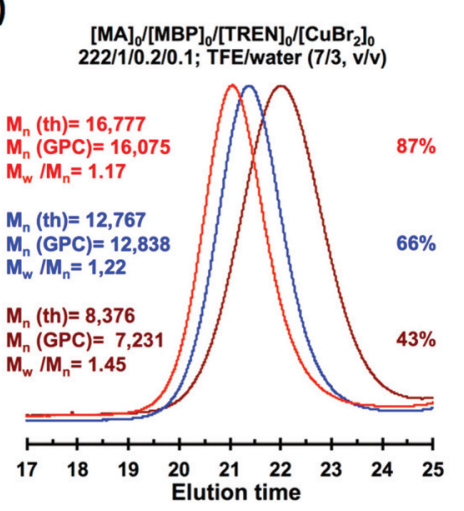

c)

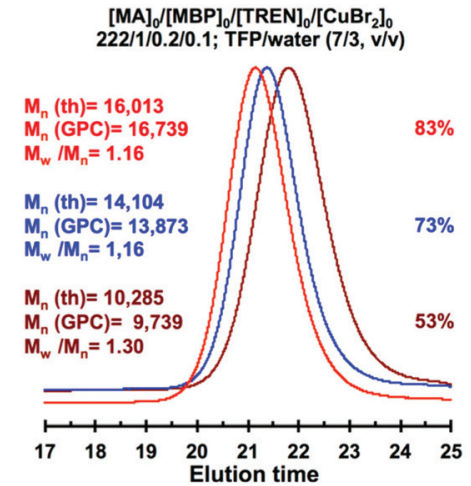

Fig. 6 GPC traces of PMA obtained by SET-LRP of MA initiated with MBP and catalyzed by nonactivated Cu (0) wire at $25^{\circ} \mathrm{C}$ in (a) TFE/water ( $8 / 2$, $\mathrm{v} / \mathrm{v}$ ); (b) TFE/water $\left(7 / 3, \mathrm{v} / \mathrm{v}\right.$ ) and (c) TFP/water $(7 / 3, \mathrm{v} / \mathrm{v})$. Reaction conditions: (a) $\mathrm{MA}=1 \mathrm{~mL}$, TFE + water $=0.5 \mathrm{~mL},[\mathrm{MA}]_{0} /[\mathrm{MBP}]_{0} /\left[\mathrm{Me}{ }_{6}-\mathrm{TREN}_{0}=\right.$ $222 / 1 / 0.1$ and $(b$ and $c)[M A]_{0} /[M B P]_{0} /[T R E N]_{0} /\left[\mathrm{CuBr}_{2}\right]_{0}=222 / 1 / 0.2 / 0.1$.

80 times less expensive and at least in biphasic systems it has been shown to be as efficient as $\mathrm{Me}_{6}$-TREN. Importantly, the external addition of the $\mathrm{Cu}(\mathrm{II}) \mathrm{Br}_{2}$ deactivator to the water phase was necessary to produce well-defined polyacrylates when switching from $\mathrm{Me}_{6}$-TREN to TREN. In the next series of experiments, the above first time presented "programmed" biphasic systems based on the mixtures of TFE and TFP with water were reinvestigated using TREN as the ligand (Scheme 1b).

Fig. 7 and 8 depict the kinetic experiments in both alcohol/ water systems and Table 2 summarizes the obtained kinetic data. Fig. 7a demonstrates that the straightforward replacement of $\mathrm{Me}_{6}$-TREN by TREN was not successful in a TFE/water $9 / 1, \mathrm{v} / \mathrm{v}$ system because it resulted in the loss of all the living features described above (Fig. 7a vs. Fig. 1b). However, all the tested $\mathrm{TFE} /$ water and $\mathrm{TFP} /$ water compositions recover first order kinetics and a linear evolution of experimental $M_{\mathrm{n}}$ with conversion in the presence of externally added $\mathrm{Cu}(\mathrm{II}) \mathrm{Br}_{2}$ under the following conditions: $[\mathrm{MA}] /[\mathrm{MBP}] /[\mathrm{TREN}] /\left[\mathrm{CuBr}_{2}\right]=222 / 1 /$ $0.2 / 0.1$. Based on previous studies reported by our laboratory, ${ }^{40,47}[\mathrm{TREN}] /\left[\mathrm{CuBr}_{2}\right]$ molar ratio $2 / 1$ was used to complex the added $\mathrm{Cu}(\mathrm{II}) \mathrm{Br}_{2}$ and the potentially formed $\mathrm{Cu}(\mathrm{I}) \mathrm{Br}$ that must be partitioned by the ligand between the organic and aqueous phases and also be disproportionated in the water phase. It is important to point out that the use of TREN and externally added $\mathrm{Cu}(\mathrm{II}) \mathrm{Br}_{2}$ instead of $\mathrm{Me}_{6}$-TREN resulted in slower polymerizations. For example, the polymerization of MA in a TFP/water $8 / 2, \mathrm{v} / \mathrm{v}$ showed $k_{\mathrm{p}}^{\text {app }}=0.031 \mathrm{~min}^{-1}$ for the $\mathrm{Me}_{6}$-TREN systems but decreased to $0.019 \mathrm{~min}^{-1}$ when $\mathrm{Me}_{6}-$ TREN was replaced by TREN (compare Table 1, entry 7 and Table 2, entry 6). Nevertheless, comparable levels of control
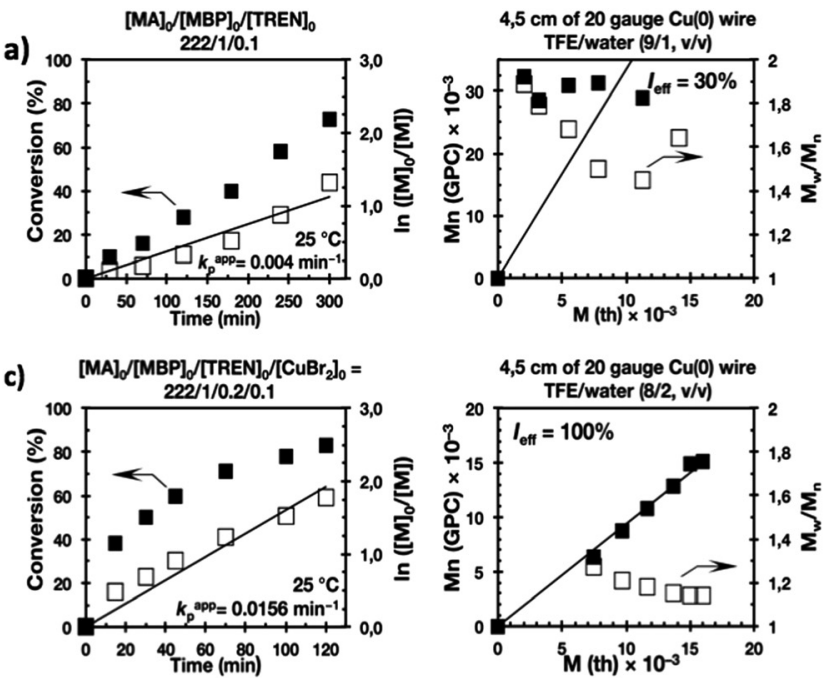
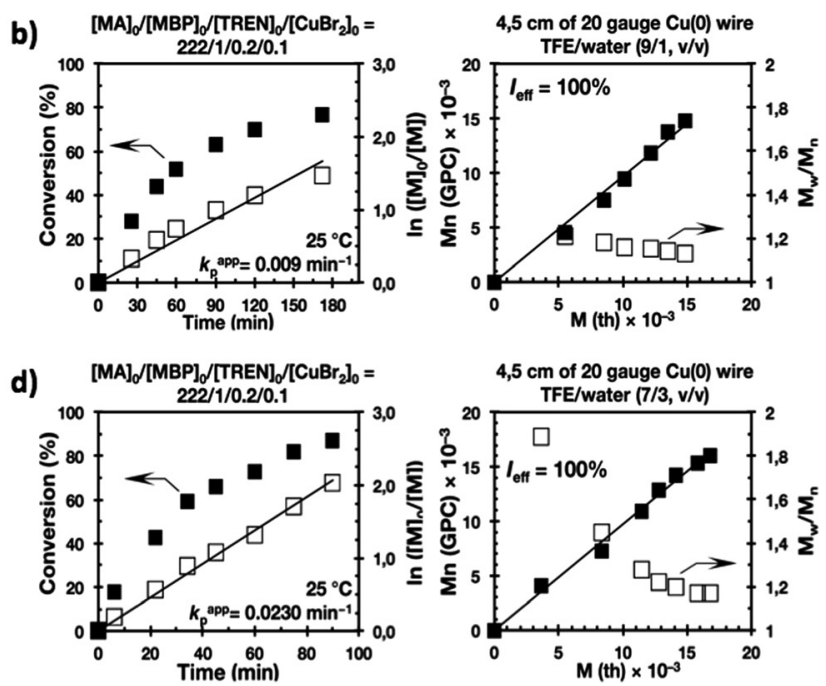

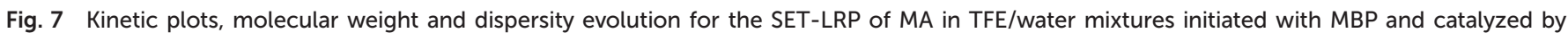

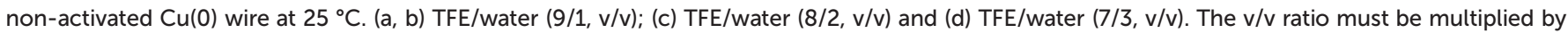

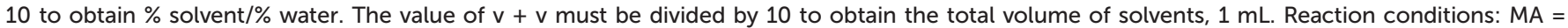
$1 \mathrm{~mL}, \mathrm{TFP}+$ water $=0.5 \mathrm{~mL}$, (a) $[\mathrm{MA}]_{0} /[\mathrm{MBP}]_{0} /[\mathrm{TREN}]_{0}=222 / 1 / 0.1,(\mathrm{~b}-\mathrm{d})[\mathrm{MA}]_{0} /[\mathrm{MBP}]_{0} /\left[\mathrm{TREN}_{0} /[\mathrm{CuBr}]_{0}=222 / 1 / 0.2 / 0.1\right.$. 
a) $[\mathrm{MA}]_{0}[\mathrm{MBP}]_{0} /[\mathrm{TREN}]_{0} /\left[\mathrm{CuBr}_{2}\right]_{0}=$

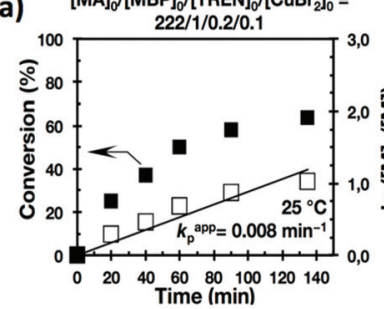

c)

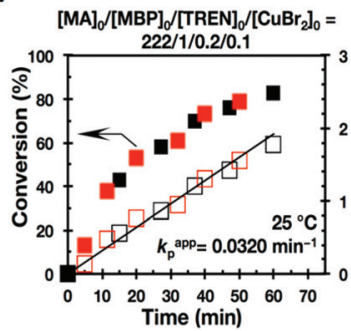

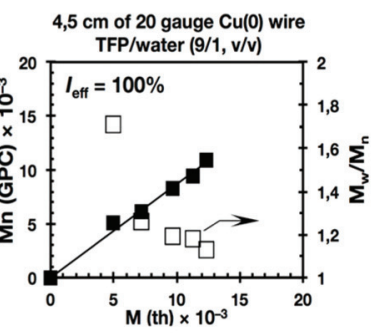

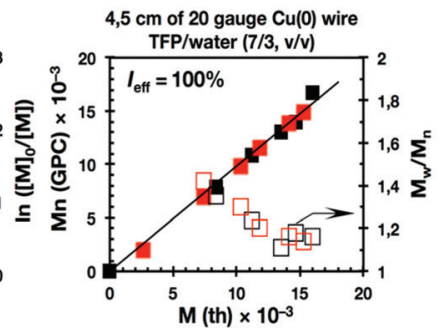

b)
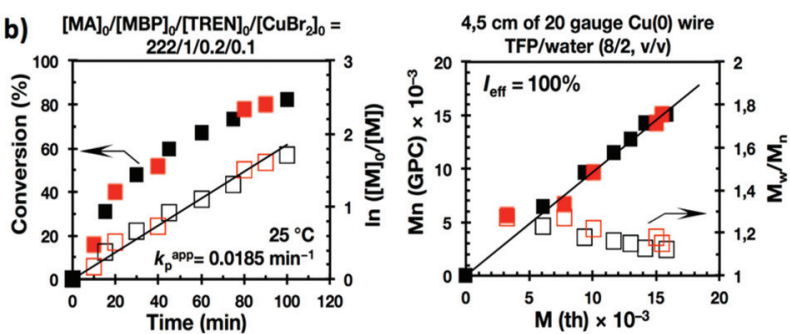

d)

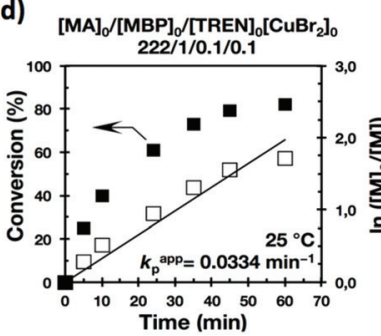

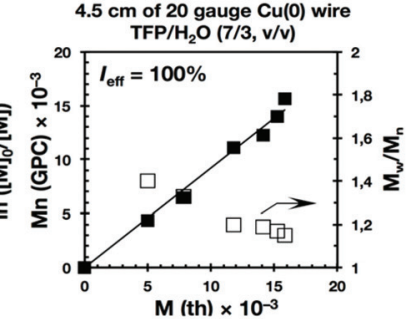

Fig. 8 Kinetic plots, molecular weight and dispersity evolution for the SET-LRP of MA in TFP/water mixtures initiated with MBP and catalyzed by non-activated $\mathrm{Cu}(0)$ wire at $25^{\circ} \mathrm{C}$. (a) TFP/water (9/1, v/v); (b) TFP/water $(8 / 2, \mathrm{v} / \mathrm{v})$ and (c and d) TFP/water $(7 / 3$, v/v). The v/v ratio must be multiplied by 10 to obtain \% solvent/\% water. The value of $\mathrm{v}+\mathrm{v}$ must be divided by 10 to obtain the total volume of solvents, $1 \mathrm{~mL}$. Reaction conditions: $\mathrm{MA}=$ $1 \mathrm{~mL}, \mathrm{TFP}+$ water $=0.5 \mathrm{~mL},[\mathrm{MA}]_{0} /[\mathrm{MBP}]_{0} /[\mathrm{TREN}]_{0} /\left[\mathrm{CuBr}_{2}\right]_{0}=222 / 1 / 0.2 / 0.1(\mathrm{a}-\mathrm{c}),[\mathrm{MA}]_{0} /[\mathrm{MBP}]_{0} /[\mathrm{TREN}]_{0} /\left[\mathrm{CuBr}_{2}\right]_{0}=222 / 1 / 0.1 / 0.1(\mathrm{~d})$. Experimental data in different colors were obtained from different kinetics experiments sometimes performed by different researchers.

Table 2 SET-LRP of MA in biphasic mixtures of water with 2,2,2-trifluoroethanol (TFE) and 2,2,3,3-tetrafluoro-1-propanol (TFP) mediated with TREN and $\mathrm{CuBr}_{2}$, catalyzed by nonactivated $4.5 \mathrm{~cm}$ of 20 gauge $\mathrm{Cu}(0)$ wire. Reaction conditions: Monomer $=1 \mathrm{~mL}$; solvent + water $=0.5 \mathrm{ml}$. The v/v ratio must be multiplied by 10 to obtain \% solvent/\% water. The value of $v+v$ must be divided by 20 to obtain the total volume of solvents, $0.5 \mathrm{~mL}$

\begin{tabular}{|c|c|c|c|c|c|c|c|c|}
\hline Entry & Reaction medium & Reactions conditions & $\begin{array}{l}k_{\mathrm{p}}^{\mathrm{app}} \\
\left(\min ^{-1}\right)\end{array}$ & $k_{\mathrm{p}(\mathrm{s}+\mathrm{w})}^{\mathrm{app}} / k_{\mathrm{p}(\mathrm{s}+\mathrm{w})}^{\text {app }}{ }^{a}$ & $\begin{array}{l}\text { Reaction } \\
\text { time }^{b} \text { (min) }\end{array}$ & $\begin{array}{l}\text { Conv. } \\
(\%)\end{array}$ & $\left(M_{\mathrm{w}} / M_{\mathrm{n}}\right)$ & $\begin{array}{l}I_{\text {eff }}{ }^{c} \\
(\%)\end{array}$ \\
\hline 1 & $\mathrm{TFE} / \mathrm{H}_{2} \mathrm{O}(9 / 1, \mathrm{v} / \mathrm{v})$ & {$[\mathrm{MA}] /[\mathrm{MBP}] /[\mathrm{TREN}] 222 / 1 / 0.1$} & 0.004 & - & 300 & 73 & 1.64 & 30 \\
\hline 3 & $\mathrm{TFE} / \mathrm{H}_{2} \mathrm{O}(8 / 2, \mathrm{v} / \mathrm{v})$ & {$[\mathrm{MA}] /[\mathrm{MBP}] /[\mathrm{TREN}] /\left[\mathrm{CuBr}_{2}\right] 222 / 1 / 0.2 / 0.1$} & 0.016 & 1.77 & 120 & 83 & 1.14 & 100 \\
\hline 4 & $\mathrm{TFE} / \mathrm{H}_{2} \mathrm{O}(7 / 3, \mathrm{v} / \mathrm{v})$ & {$[\mathrm{MA}] /[\mathrm{MBP}] /[\mathrm{TREN}] /\left[\mathrm{CuBr}_{2}\right] 222 / 1 / 0.2 / 0.1$} & 0.023 & 2.55 & 90 & 87 & 1.17 & 100 \\
\hline 7 & $\mathrm{TFP} / \mathrm{H}_{2} \mathrm{O}(7 / 3, \mathrm{v} / \mathrm{v})$ & {$[\mathrm{MA}] /[\mathrm{MBP}] /[\mathrm{TREN}] /\left[\mathrm{CuBr}_{2}\right] 222 / 1 / 0.2 / 0.1$} & 0.032 & 4.00 & 50 & 83 & 1.16 & 100 \\
\hline 8 & $\mathrm{TFP} / \mathrm{H}_{2} \mathrm{O}(7 / 3, \mathrm{v} / \mathrm{v})$ & {$[\mathrm{MA}] /[\mathrm{MBP}] /[\mathrm{TREN}] /\left[\mathrm{CuBr}_{2}\right] 222 / 1 / 0.1 / 0.1$} & 0.033 & 4.12 & 60 & 82 & 1.15 & 100 \\
\hline $9^{d}$ & $\mathrm{TFE} / \mathrm{H}_{2} \mathrm{O}(8 / 2, \mathrm{v} / \mathrm{v})$ & {$[\mathrm{MA}] /[\mathrm{MBP}] /[\mathrm{TREN}] /\left[\mathrm{CuBr}_{2}\right]$ 222/1/0.2/0.1 } & 0.015 & - & 120 & 82 & 1.16 & 96 \\
\hline $10^{e}$ & $\mathrm{TFE} / \mathrm{H}_{2} \mathrm{O}(8 / 2, \mathrm{v} / \mathrm{v})$ & {$[\mathrm{MA}] /[\mathrm{MBP}] /[\mathrm{TREN}] /\left[\mathrm{CuBr}_{2}\right] 222 / 1 / 0.2 / 0.1$} & 0.013 & - & 120 & 75 & 1.18 & 87 \\
\hline $11^{d}$ & $\mathrm{TFE} / \mathrm{H}_{2} \mathrm{O}(8 / 2, \mathrm{v} / \mathrm{v})$ & {$[\mathrm{MA}] /[\mathrm{MBP}] /[\mathrm{TREN}] /\left[\mathrm{CuBr}_{2}\right]$ 222/1/0.1/0.05 } & 0.019 & - & 90 & 81 & 1.15 & 89 \\
\hline
\end{tabular}

${ }^{a}$ Correspond to the $k_{\mathrm{p}}^{\text {app }}$ of $(9 / 1 \mathrm{v} / \mathrm{v})$ of SET-LRP experiments mediated by TREN. ${ }^{b}$ The reaction time to the monomer conversion (\%) is reported in the next column. ${ }^{c}$ Initiator efficiency. ${ }^{d} 2.0 \mathrm{~cm}$ of 20 gauge non-activated $\mathrm{Cu}(0)$ wire was used. ${ }^{e} 12.5 \mathrm{~cm}$ of 20 gauge non-activated $\mathrm{Cu}(0)$ wire was used.

were observed in both systems as indicated by systematic $I_{\text {eff }}$ values close to $100 \%$ and $M_{\mathrm{w}} / M_{\mathrm{n}}$ values at around $\sim 1.15$, indistinctly (Table 2, entries 2-7). Fig. 6b and c show representative GPC traces of PMA obtained in TFE/water and TFP/water $7 / 3$, $\mathrm{v} / \mathrm{v}$ systems. As expected, the increment of the volume ratio of water from $9 / 1$ to $8 / 2$ and to $7 / 3$ was accompanied in both systems by a dramatic increase of $k_{\mathrm{p}}^{\text {app }}$. Remarkably, an increase in the TFP/water volume ratio from $9 / 1$ to $7 / 3$ increases the $k_{\mathrm{p}}^{\text {app }}$ by a factor of $4.00\left(0.0032 \mathrm{~min}^{-1} v s\right.$.
$0.008 \mathrm{~min}^{-1}$ ). Notice also that a linear increase of the $k_{\mathrm{p}}^{\text {app }}$ with the increase of the $\Phi_{\mathrm{H}_{2} \mathrm{O}}$ was observed in both TFE/water and TFP/water SET-LRP systems (Fig. 9a and b, respectively). An additional experiment shown in Fig. 8d demonstrates that the living behavior in these series of experiments is also retained when using $[\mathrm{TREN}] /\left[\mathrm{CuBr}_{2}\right]$ molar ratio $1 / 1$ (Table 2 entry 8). However, a detailed series of experiments with different ratios of [TREN $] /\left[\mathrm{CuBr}_{2}\right]$ molar ratios will be discussed in a publication dedicated entirely to this topic. 
a)

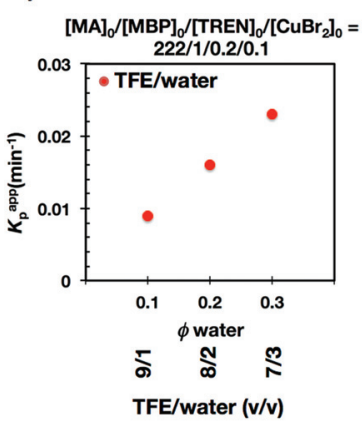

b)

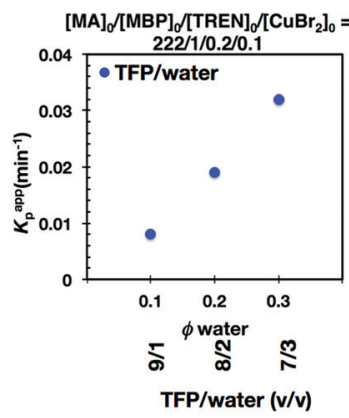

Fig. 9 The dependence of $k_{\mathrm{p}}^{\text {app }}$ with the volume fraction of water $\left(\Phi_{\mathrm{H}_{2} \mathrm{O}}\right)$ on the SET-LRP of MA initiated with MBP mediated TREN/Cu(॥) $\mathrm{Br}_{2}$ and catalyzed by $4.5 \mathrm{~cm}$ of non-activated $\mathrm{Cu}(0)$ wire in (a) TFE/water and (b) TFP/water mixtures.

All the tested compositions were biphasic as can be seen from the digital images taken after the SET-LRP process (Fig. 10). However, the analysis of these images suggests better dispersion of the water phase containing $\mathrm{Cu}(\mathrm{II}) \mathrm{Br}_{2}$ and TREN in the organic phase at low $\Phi_{\mathrm{H}_{2} \mathrm{O}}$. Nevertheless, there is no doubt that the SET-LRP process takes place in a biphasic regime when the alcohol/water volume ratio is $7 / 3, \mathrm{v} / \mathrm{v}$.

Chain-end analysis of PMA obtained by the SET-LRP process catalyzed by non-activated $\mathrm{Cu}(0)$ wire mediated by $\mathrm{Me}_{6}$-TREN and TREN in a TFE containing $20 \%$ water

A "programmed" biphasic system based on TFE was selected to perform a representative experiment directed to analyze the

a)

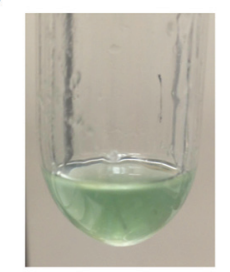

TFE/water 9/1

d)

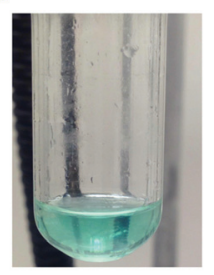

TFP/water 9/1 b)

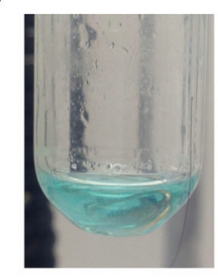

TFE/water $8 / 2$

e)

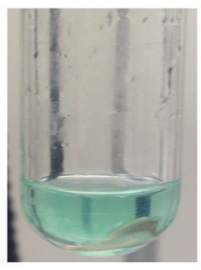

TFP/water 8/2 c)

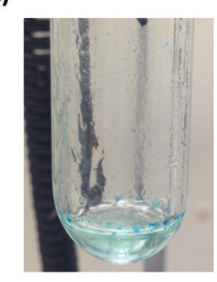

TFE/water $7 / 3$

f)

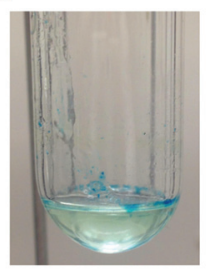

TFP/water $7 / 3$

Fig. 10 Visualization of the reaction mixture after SET-LRP of MA initiated with $\mathrm{MBP}$ and catalyzed by non-activated $\mathrm{Cu}(0)$ wire at $25^{\circ} \mathrm{C}$ in (a) TFE/water $(9 / 1, \mathrm{v} / \mathrm{v})$; (b) TFE/water $(8 / 2, \mathrm{v} / \mathrm{v})$; (c) TFE/water $(7 / 3, \mathrm{v} / \mathrm{v})$; (e) TFP/water $(9 / 1, \mathrm{v} / \mathrm{v})$; (e) TFP/water $(8 / 2, \mathrm{v} / \mathrm{v})$ and (f) TFP/water $(7 / 3$, $\mathrm{v} / \mathrm{v})$. Reaction conditions: $M A=1 \mathrm{~mL}$, Fluorinated solvent (TFE/TFP) + water $=0.5 \mathrm{~mL},[\mathrm{MA}]_{0} /[\mathrm{MBP}]_{0} /[\mathrm{TREN}]_{0} /\left[\mathrm{CuBr}_{2}\right]_{0}=222 / 1 / 0.2 / 0.1$.

chain ends of PMA isolated from the above presented biphasic SET-LRP systems catalyzed by non-activated $\mathrm{Cu}(0)$ wire using $\mathrm{Me}_{6}$-TREN and TREN. TFE is technologically more attractive than TFP because it is commercially available at lower prices and has a lower boiling point $\left(74.05{ }^{\circ} \mathrm{C} v\right.$ s. $\left.107-108{ }^{\circ} \mathrm{C}\right)$. Low molar mass PMA samples were isolated at around 90\% monomer conversion after the SET-LRP process in a TFE/water mixture $8 / 2, \mathrm{v} / \mathrm{v}$ at a $[\mathrm{MA}]_{0} /[\mathrm{MBP}]_{0}=50$. The analysis of the polymer chain-ends before and after "thio-bromo click" functionalization by a combination of $500 \mathrm{MHz}{ }^{1} \mathrm{H}-\mathrm{NMR}$ and MALDI-TOF is a powerful combination of analytical methods to assess the chain-end functionality of polymers prepared by any LRP technique. Fig. 11 shows the $500 \mathrm{MHz}{ }^{1} \mathrm{H}-\mathrm{NMR}$ spectra of PMA isolated at $86 \%$ conversion after the $\mathrm{Me}_{6}$ TREN-mediated SET-LRP before and after the modification of the bromine chain ends with thiophenol via a "thio-bromo click" thioetherification reaction (see Scheme 1d). ${ }^{55,56}$

Taking into account the experimental error, the high degree of bromine functionality $(f)$ determined for the isolated PMA ( $f=99 \%$ ) endorses the excellent SET-LRP conditions to this combination of catalyst, solvents and ligand. Fig. 12 supports that the transition from the non-activated $\mathrm{Cu}(0)$ wire $/ \mathrm{Me}_{6}{ }^{-}$ TREN to non-activated $\mathrm{Cu}(0)$ wire/TREN/Cu(II)Br $\mathrm{Br}_{2}$ catalytic system does not compromise the fraction of chains that are functionalized with a bromine atom at high conversion. In this case chain-end functionality was determined to be $96 \%$. Hence, both catalytic systems ensure near perfect bromine chain end functionality of the PMA regardless of the biphasic nature of the reaction mixture generated in the presence of TFE containing $20 \%$ water. Modification of the bromine chain ends of both PMA samples with thiophenol was also monitored by MALDI-TOF spectrometry (Fig. 13 and 14). The presence of only one distribution after the thioetherification step, which appears shifted 29 mass units above the original series of PMA-Br, also supports high chain end fidelity for both catalytic systems in this mixture of solvents. These results are comparable to those obtained using previously described "programmed" biphasic SET-LRP systems based on both disproportionating and non-disproportionating solvents as well as homogeneous systems based on TFE and TFP in the absence of water.

\section{Biphasic SET-LRP processes tolerate both the use of excess of} $\mathrm{Cu}(0)$ wire and of $\mathrm{Cu}(\mathrm{II}) \mathrm{Br}_{2}$

The last series of experiments were performed to bring out one of the most important features of biphasic SET-LRP processes. Biphasic SET-LRP provides a "self-controlled" reversible deactivation that does not provide the side reactions encountered in homogeneous systems when an excess of $\mathrm{Cu}(\mathrm{II}) \mathrm{Br}_{2}$ is used during the polymerization. ${ }^{15,16}$ This important characteristic relies on the partitioning of reagents between phases because reversible deactivation occurs at the interface of the two phases. The same is the case also for the amount of $\mathrm{Cu}(0)$ wire. To support these statements, the SET-LRP of MA was investigated using the TREN/Cu(II) $\mathrm{Br}_{2}$ catalytic system in a TFE containing $20 \%$ water in the presence of different amounts of $\mathrm{Cu}(0)$ wire and $\mathrm{Cu}(\mathrm{II}) \mathrm{Br}_{2}$ (Fig. 15 and 16, respectively). Table 2 
a)

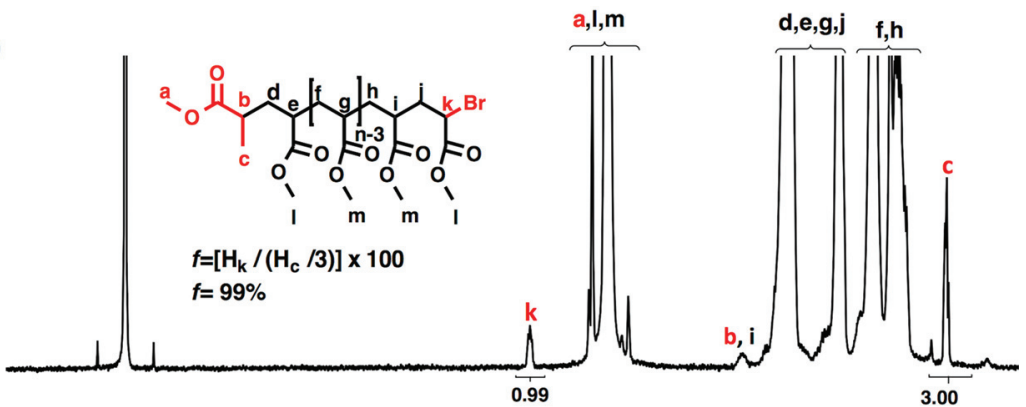

b)

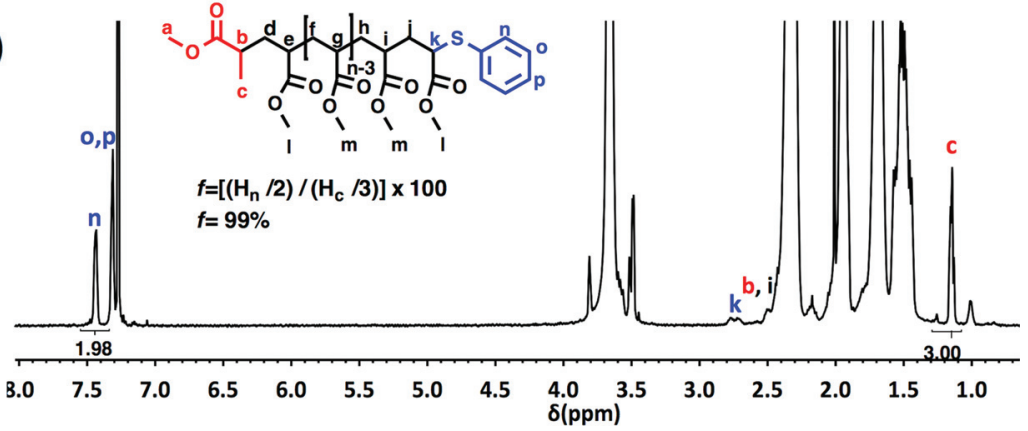

Fig. $11{ }^{1} \mathrm{H}-\mathrm{NMR}\left(500 \mathrm{MHz}\right.$ ) recorded in $\mathrm{CDCl}_{3}$, of $\mathrm{PMA}-\mathrm{Br}$ isolated at $86 \%$ conversion from SET-LRP of MA in TFE/water (8/2, v/v) mixtures initiated with MBP and catalyzed by nonactivated $\mathrm{Cu}(0)$ wire at $25^{\circ} \mathrm{C}$. (a) Before the "thio-bromo click" reaction. (b) After the "thio-bromo click" reaction. Reaction conditions: $M A=1 \mathrm{~mL}, \mathrm{TFE}+$ water $=0.5 \mathrm{~mL},[\mathrm{MA}]_{0} /[\mathrm{MBP}]_{0} /\left[\mathrm{Me}_{6}-\mathrm{TREN}\right]_{0}=50 / 1 / 0.1,4.5 \mathrm{~cm}$ of 20 gauge $\mathrm{Cu}(0)$ wire.

a)
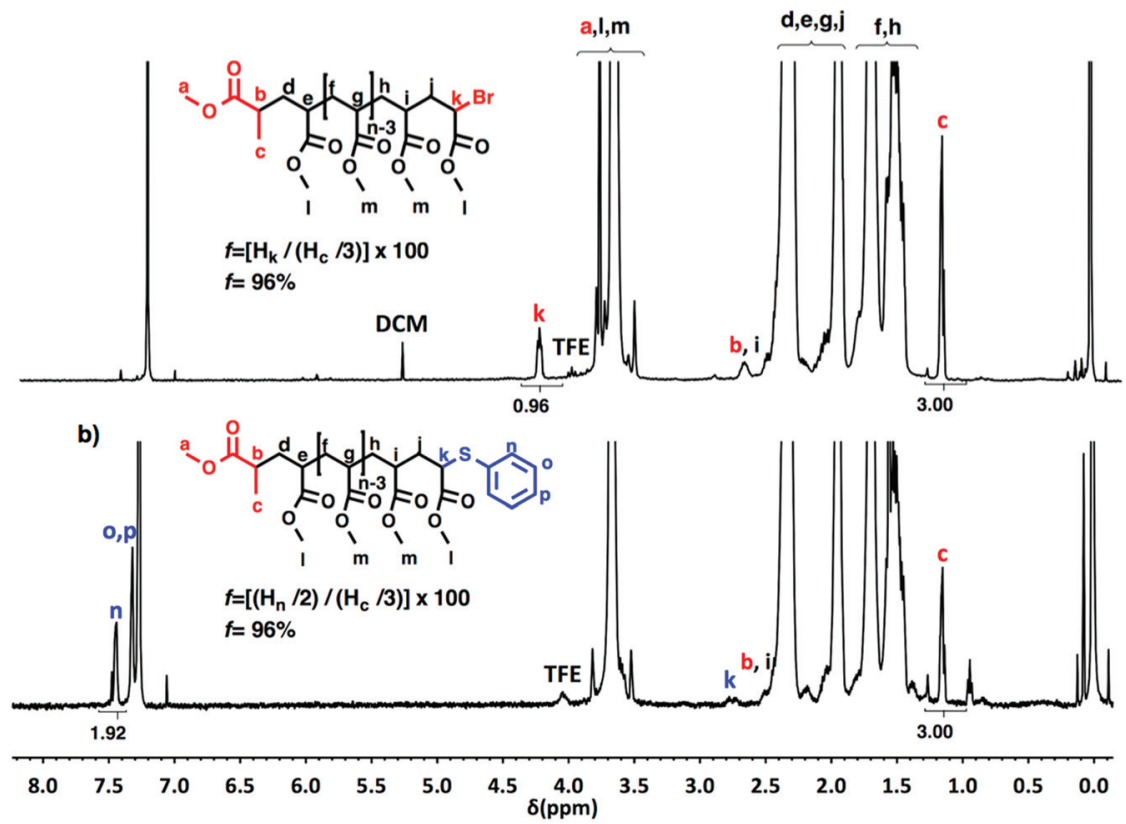

Fig. $12{ }^{1} \mathrm{H}-\mathrm{NMR}(500 \mathrm{MHz})$ recorded in $\mathrm{CDCl}_{3}$, of $\mathrm{PMA}-\mathrm{Br}$ isolated at $88 \%$ conversion from SET-LRP of $\mathrm{MA}$ in TFE/water (8/2, v/v) mixtures initiated with MBP and catalyzed by nonactivated $\mathrm{Cu}(0)$ wire at $25^{\circ} \mathrm{C}$. (a) Before the "thio-bromo click" reaction. (b) After the "thio-bromo click" reaction. Reaction conditions: $\mathrm{MA}=1 \mathrm{~mL}$, TFE + water $=0.5 \mathrm{~mL},[\mathrm{MA}]_{0} /[\mathrm{MBP}]_{0} /[\mathrm{TREN}]_{0} /\left[\mathrm{CuBr}_{2}\right]_{0}=50 / 1 / 0.2 / 0.1,4.5 \mathrm{~cm}$ of $20 \mathrm{gauge} \mathrm{Cu}(0)$ wire.

summarizes all experimental data collected from both series of experiments.

Experiments with $\mathrm{Cu}(0)$ wire lengths of $2.0,4.5$ and $12.5 \mathrm{~cm}$ were carried under the following conditions $[\mathrm{MA}]_{0} /[\mathrm{MBP}]_{0} /$
$[\mathrm{TREN}]_{0} /\left[\mathrm{Cu}(\mathrm{II}) \mathrm{Br}_{2}\right]_{0}=222 / 1 / 0.2 / 0.1$. All kinetic experiments reach about $80 \%$ conversion in 120 min reaction time and exhibit linear first order kinetics. Regardless of the $\mathrm{Cu}(0)$ wire length, the resulting PMA at the end of the polymerization 


\section{a) PMA before thioetherification}
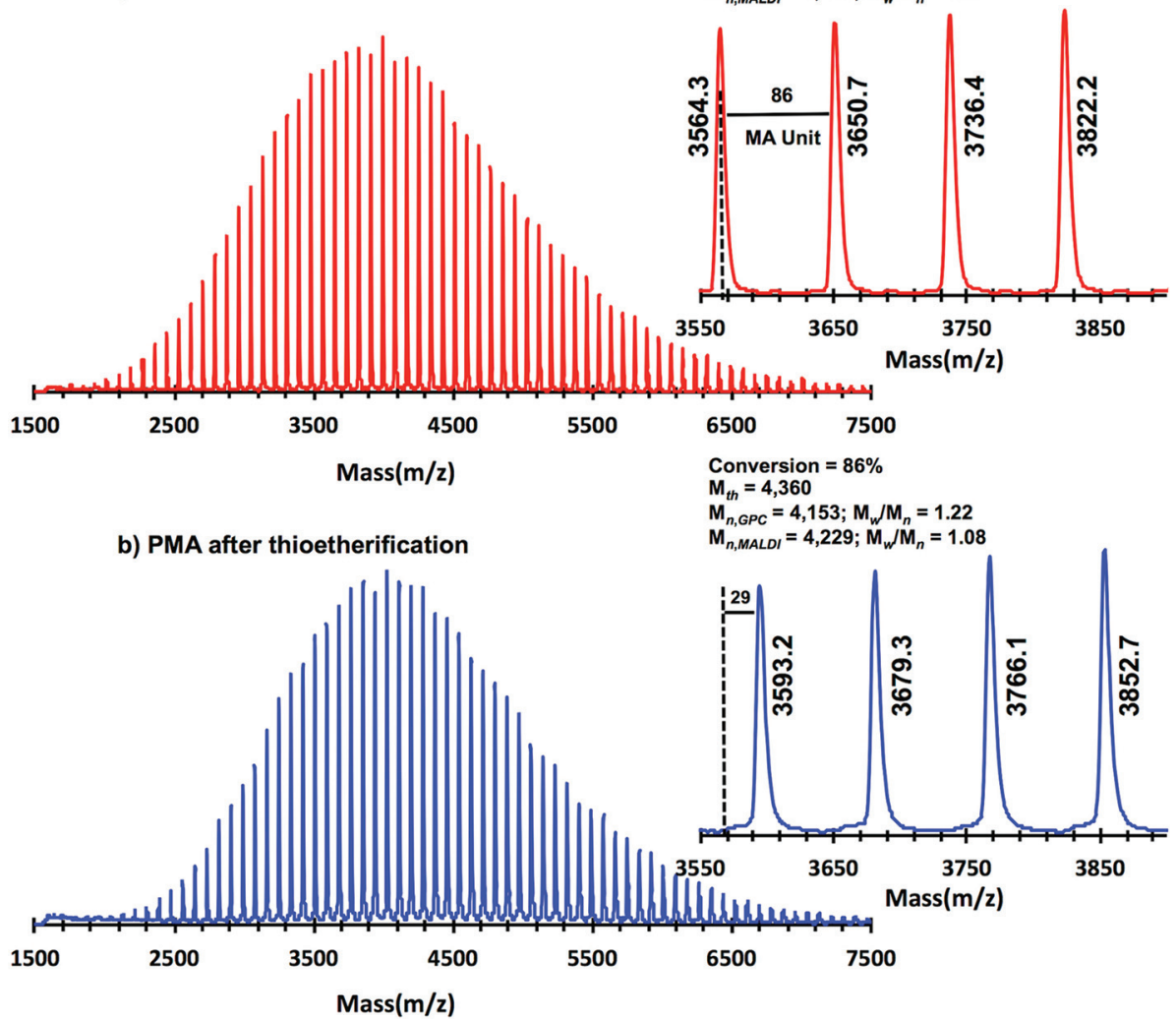

Fig. 13 MALDI-TOF of PMA-Br isolated at $86 \%$ from SET-LRP of MA in TFE/water $(8 / 2, \mathrm{v} / \mathrm{v})$ mixtures initiated with MBP and catalyzed by nonactivated $\mathrm{Cu}(0)$ wire at $25^{\circ} \mathrm{C}$. (a) Before "thio-bromo click" reaction. (b) After "thio-bromo click" reaction. Reaction conditions: $\mathrm{MA}=1 \mathrm{~mL}$, TFE + water $=0.5 \mathrm{~mL}$, $[\mathrm{MA}]_{0} /[\mathrm{MBP}]_{0} /\left[\mathrm{Me}_{6}-\mathrm{TREN}\right]_{0}=50 / 1 / 0.1,4.5 \mathrm{~cm}$ of 20 gauge $\mathrm{Cu}(0)$ wire. The dotted line in expansion after thioeterification shows the original peak from before thioeterification, while 29 represents the increase in molar mass after thioeterification i.e., $\mathrm{SC}_{6} \mathrm{H}_{5}(109,2)-\mathrm{Br}(79,9)=29.3$ for each chain end.

exhibits $M_{\mathrm{w}} / M_{\mathrm{n}}$ values ranging from 1.14 to 1.18 and $k_{\mathrm{p}}^{\text {app }}$ is almost $0.015 \mathrm{~min}^{-1}$ (Table 2, entries 3, 9 and 10). These results support the tolerance of this biphasic system to a large excess of $\mathrm{Cu}(0)$ in the form of wire. The tolerance of these "interfacial" or "on water" SET-LRP processes ${ }^{35-41}$ to high externally added $\mathrm{Cu}(\mathrm{II}) \mathrm{Br}_{2}$ deactivator loadings was investigated by increasing the amount of $\mathrm{Cu}(\mathrm{II}) \mathrm{Br}_{2}$ relative to the initiator from $5 \%$ to $10 \%$ and to $20 \%$ while maintaining a constant ratio $[\mathrm{TREN}]_{0} /\left[\mathrm{CuBr}_{2}\right]_{0}=2 / 1$. As can be seen in Fig. 16, in all cases first order kinetics with excellent control over the polymerization of MA was observed. The $k_{\mathrm{p}}^{\text {app }}$ only decreased at the highest concentration of $\mathrm{Cu}(\mathrm{II}) \mathrm{Br}_{2}$ while maintaining the same level of control as the experiments performed in the presence of lower $\mathrm{Cu}(\mathrm{II}) \mathrm{Br}_{2}$ loadings (compare Table 2, entries 3, 11 and 12).

It is important to mention at this point that regardless of the level of improvement of the SET-LRP methodology, it does not yet compete with the perfection of the living cationic polymerization of functional vinyl ethers employed in our laboratory in the late 1980 s and early $1990 \mathrm{~s},{ }^{57-61}$ with the living metathesis ring opening polymerization employed in the mid $1990 \mathrm{~s},{ }^{62,63}$ group transfer polymerization in the late $1980 \mathrm{~s},{ }^{64}$ reactions on narrow dispersity polymers in the late $1980 \mathrm{~s},{ }^{65}$ living polymerization of acetylenes ${ }^{66}$ and living cationic ring opening polymerization of cyclic imino ethers ${ }^{67}$ both in the late 1990s that were used in the construction of complex macromolecular systems. Neither ATRP ${ }^{68}$ nor other metal catalyzed living radical polymerizations ${ }^{69,70}$ are competitive with the previously mentioned methods in spite of the very large research efforts dedicated to the field of living radical polymerization for the last more than 25 years. Modest progress made so far by SET-LRP was reported only recently. ${ }^{2,4-7,9,55,56,71}$ Iterative methods for the synthesis of sequence defined monodisperse macromolecules and their use in the construction of complex macromolecular systems became successful only in $2015 .^{72,73}$ Therefore, conventional radical polymerization ${ }^{74-78}$ has remained so far the method of choice employed in the synthesis of complex macromolecular systems. We believe that rather than debating mechanisms, improving methodologies by elucidating in a constructive way their mechanism up to the point that will transform living radical polymerization into a technique competitive with much older living polymerization methods would be, in our opinion, more efficient and desirable. 


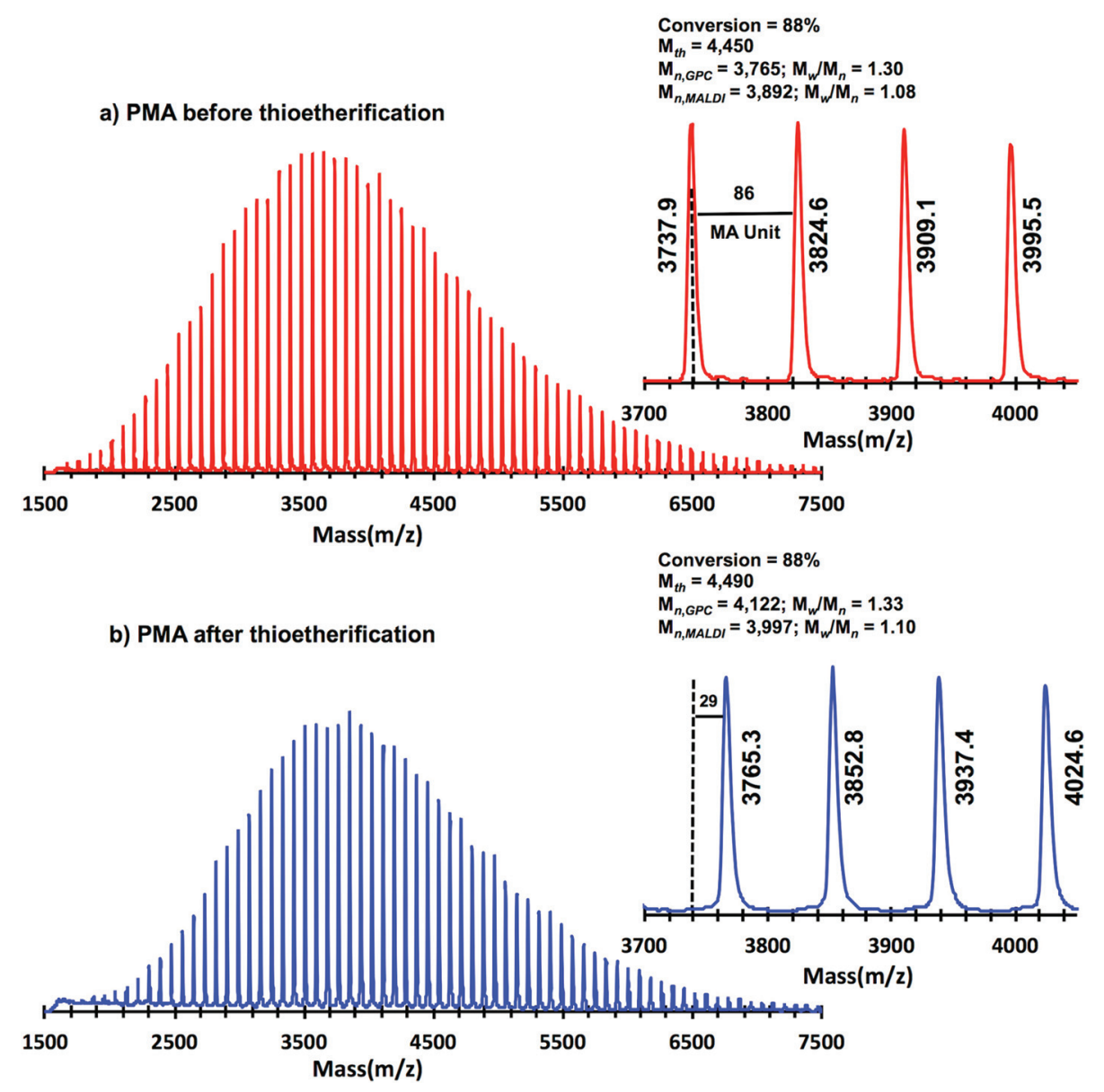

Fig. 14 MALDI-TOF of PMA-Br isolated at $88 \%$ from SET-LRP of MA in TFE/water (8/2, v/v) mixtures initiated with MBP, catalyzed by nonactivated Cu(0) wire at $25{ }^{\circ} \mathrm{C}$. (a) Before the "thio-bromo click" reaction. (b) After the "thio-bromo click" reaction. Reaction conditions: $\left.[\mathrm{MA}]_{0} /[\mathrm{MBP}]_{0} /[\mathrm{TREN}]_{0} /[\mathrm{CuBr}]_{0}\right]_{0}=$ $50 / 1 / 0.2 / 0.1, M A=1 \mathrm{~mL}$, TFE + water $=0.5 \mathrm{~mL} .4 .5 \mathrm{~cm}$ of 20 gauge $\mathrm{Cu}(0)$ wire. The dotted line in expansion after thioeterification shows the original peak from before thioeterification, while 29 represents the increase in molar mass after thioeterification i.e., $\mathrm{SC}_{6} \mathrm{H}_{5}(109,2)-\mathrm{Br}(79,9)=29.3$ for each chain end.
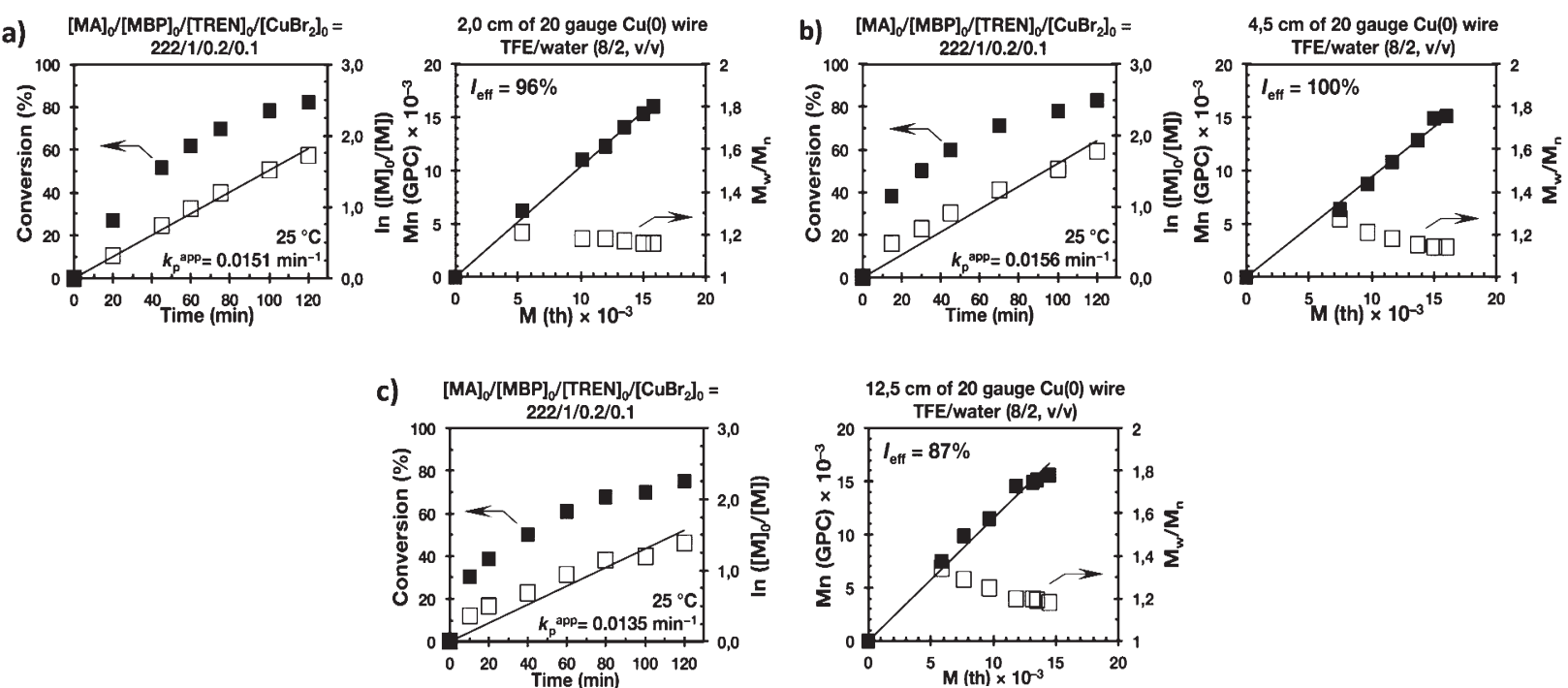

Fig. 15 Kinetic plots, molecular weight and dispersity evolution for the SET-LRP of MA in TFE/water mixtures initiated with MBP and catalyzed by nonactivated $\mathrm{Cu}(0)$ wire at $25^{\circ} \mathrm{C}$. (a-c) TFE/water $(8 / 2, \mathrm{v} / \mathrm{v})$. The $\mathrm{v} / \mathrm{v}$ ratio must be multiplied by 10 to obtain \% solvent/\% water. The value of $\mathrm{v}+\mathrm{v}$ must be divided by 10 to obtain the total volume of solvents, $1 \mathrm{~mL}$. Reaction conditions: $\mathrm{MA}=1 \mathrm{~mL}, \mathrm{TFP}+$ water $=0.5 \mathrm{~mL}$, $[\mathrm{MA}]_{0} /[\mathrm{MBP}]_{0} /[\mathrm{TREN}]_{0} /$ $\left[\mathrm{CuBr}_{2}\right]_{0}=222 / 1 / 0.2 / 0.1$. 

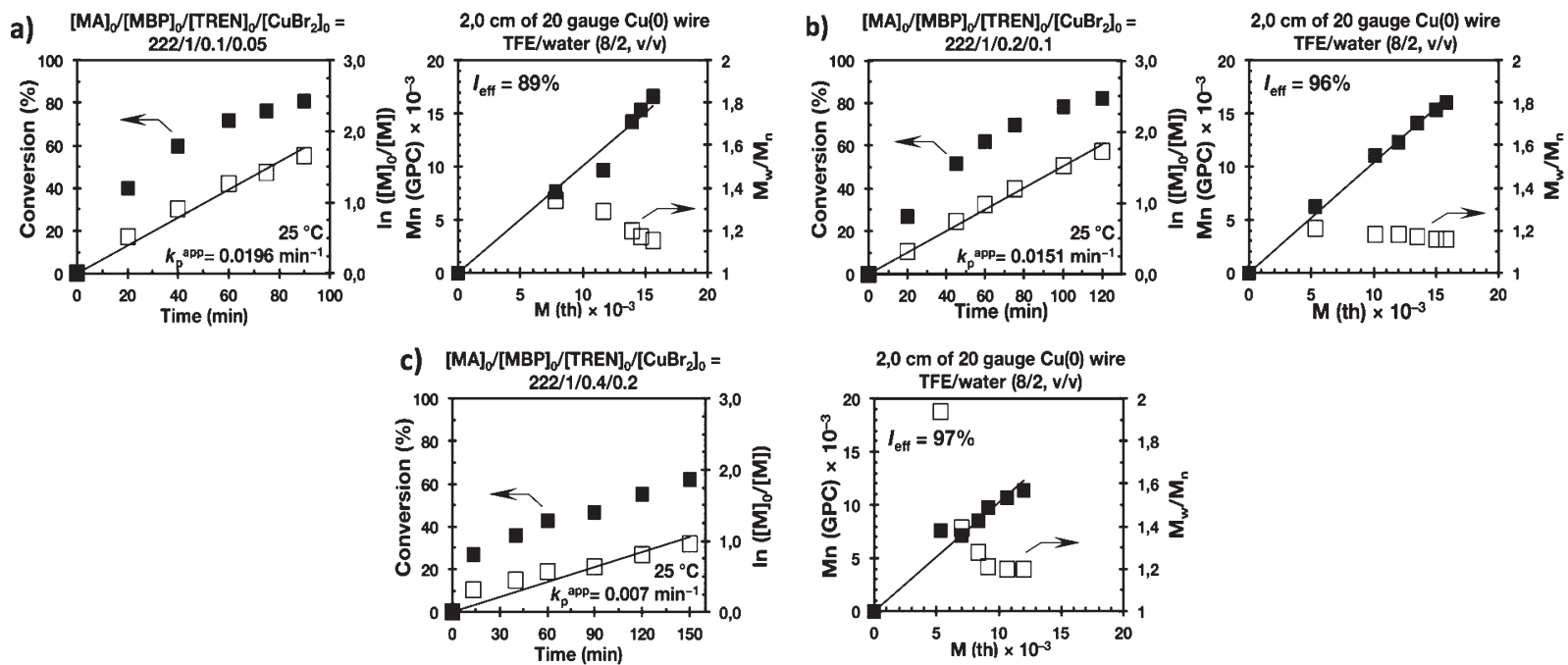

Fig. 16 Kinetic plots, molecular weight and dispersity evolution for the SET-LRP of MA in TFE/water mixtures initiated with MBP and catalyzed by nonactivated $\mathrm{Cu}(0)$ wire at $25^{\circ} \mathrm{C}$. (a-c) TFE/water $(8 / 2, v / v)$. The $v / v$ ratio must be multiplied by 10 to obtain $\%$ solvent/\% water. The value of $v+v$ must be divided by 10 to obtain the total volume of solvents, $1 \mathrm{~mL}$. Reaction conditions: $\mathrm{MA}=1 \mathrm{~mL}, \mathrm{TFP}+$ water $=0.5 \mathrm{~mL}$, (a) $[\mathrm{MA}]_{0} /[\mathrm{MBP}]_{0} /$ $[\text { TREN }]_{0} /\left[\mathrm{CuBr}_{2}\right]_{0}=222 / 1 / 0.1 / 0.05$, (b) $[\mathrm{MA}]_{0} /[\mathrm{MBP}]_{0} /[\mathrm{TREN}]_{0} /[\mathrm{CuBr}]_{0}=222 / 1 / 0.2 / 0.1$, (c) $[\mathrm{MA}]_{0} /[\mathrm{MBP}]_{0} /\left[\mathrm{TREN}_{0} /[\mathrm{CuBr}]_{0}=222 / 1 / 0.4 / 0.2\right.$.

\section{Conclusions}

This report demonstrates the synthesis of PMA via SET-LRP initiated with MBP in biphasic mixtures of water with fluorinated alcohols. Mixtures of TFE and TFP containing 10, 20, and $30 \%$ water provided a living polymerization in the presence of two catalytic systems: non-activated $\mathrm{Cu}(0)$ wire $/ \mathrm{Me}_{6}{ }^{-}$ TREN and non-activated $\mathrm{Cu}(0)$ wire/TREN/Cu(II)Br$r_{2}$. SET-LRP of MA in this combination of solvents evolved into biphasic reaction mixtures due to the immiscibility between the aqueous phase containing $\mathrm{Cu}(\mathrm{II}) \mathrm{Br}_{2}$ and the ligand and the alcohol phase containing the monomer and polymer. This was validated through kinetic experiments showing linear evolution of $\ln \left([\mathrm{M}]_{\mathrm{o}} /[\mathrm{M}]\right)$ vs. polymerization time, linear dependence of experimental $M_{\mathrm{n}}$ on conversion, narrow molecular weight distribution and almost quantitative chain end functionality at high conversion. For example, low $M_{\mathrm{n}}$ PMA samples showed near perfect retention of end group fidelity regardless of the catalytic system used. SET-LRP of MA in this combination of fluorinated alcohols and water evolved into biphasic reaction mixtures. According to the required disproportionation of $\mathrm{Cu}(\mathrm{I}) \mathrm{X}$ into $\mathrm{Cu}(0)$ and $\mathrm{Cu}(\mathrm{II}) \mathrm{X}_{2}$, a linear relationship between the $k_{\mathrm{p}}^{\text {app }}$ of the SET-LRP process and the $\Phi_{\mathrm{H}_{2} \mathrm{O}}$ was observed. Thus, simply changing the polarity balance of the reaction mixture a rate enhancement of up to four times was achieved. Also important is to highlight that the SET-LRP of MA in a TFE/water 8/2, v/v performed well also in the presence of excess of $\mathrm{Cu}(0)$ wire or $\mathrm{Cu}(\mathrm{II}) \mathrm{Br}_{2}$, unlike the corresponding single-phase systems. This important characteristic relies on the partitioning of reagents between phases occurring during biphasic SET-LRP that provides a "self-controlled" reversible deactivation at the interface of the two phases that avoids side reactions encountered in the homogeneous state when an excess of $\mathrm{Cu}(\mathrm{II}) \mathrm{X}_{2}$ is used. The same is the case also about the activation step.

\section{Experimental}

\section{Materials}

MA (99\%) (from Acros) was passed over a short column of basic $\mathrm{Al}_{2} \mathrm{O}_{3}$ before use in order to remove the radical inhibitor. Tris(2-aminoethyl)amine (TREN) (99\% Acros), $\mathrm{Cu}(0)$ wire (20 gauge wire, $0.812 \mathrm{~mm}$ diameter from Fischer), $\mathrm{CuBr}_{2}(99 \%$, Alfa Aesar), methyl 2-bromopropionate (MBP) (99\% Acros), 2,2,3,3-tetrafluoropropanol (TFP) (SynQuest Laboratories), 2,2,2-trifluoroethanol (TFE) (SynQuest Laboratories), and thiophenol (99\%, Acros) were used as received. Triethylamine $\left(\mathrm{NEt}_{3}, 99.9 \%\right.$, Chemimpex) was destilled under $\mathrm{N}_{2}$ over $\mathrm{CaH}_{2}$. Tris[2-(dimethylamino)ethyl] amine ( $\mathrm{Me}_{6}$-TREN) was synthesized according to a literature procedure. ${ }^{79}$

\section{Techniques}

$500 \mathrm{MHz}{ }^{1} \mathrm{H}$-NMR spectra were recorded on a Bruker UNI500 NMR instrument at $25{ }^{\circ} \mathrm{C}$ in $\mathrm{CDCl}_{3}$ containing tretamethylsilane (TMS) as an internal standard. For the chain end analysis of PMA, the delay time (D1) applied was $10 \mathrm{~s}$ and the number of scans (nt) was 80. Gel permeation chromatography (GPC) analysis of the polymer samples was performed using a PerkinElmer Series LC 100 column oven containing three AM gel columns (a guard column, a $500 \AA$, $10 \mu \mathrm{m}$ column and a $10^{4} \AA$ A, $10 \mu \mathrm{m}$ column), a Shimadzu LC-20AD high performance liquid chromatograph pump, a PE Nelson Analytical 900 Series integration data station, a Shimadzu RID-10A refractive index (RI) detector and a Shimadzu SIL-10ADvp Autoinjector. THF (Fischer, HPLC grade) was used as an eluent at a flow rate of 
$1 \mathrm{~mL} \mathrm{~min}^{-1}$. The number-average $\left(M_{\mathrm{n}}\right)$ and weight-average $\left(M_{\mathrm{w}}\right)$ molecular weights of PMA samples were determined using poly(methyl methacrylate) (PMMA) standards purchased from American Polymer Standards. MALDI-TOF spectra were recorded in reflection mode on a Voyager DE (Applied Biosystems) equipped with a $337 \mathrm{~nm}$ nitrogen laser (3 ns pulse width). The accelerating potential was $25 \mathrm{kV}$, the grid was $88 \%$, the laser power was 1950 arbitrary units, and a positive mode was employed. The sample analysis was carried out with 2-(4hydroxyphenylazo)benzoic acid as the matrix. THF solutions of the matrix (30 $\left.\mathrm{mg} \mathrm{mL}^{-1}\right), \mathrm{NaCl}\left(10 \mathrm{mg} \mathrm{mL} \mathrm{m}^{-1}\right)$ and polymer (10 $\mathrm{mg} \mathrm{mL}^{-1}$ ) were prepared separately. The final solution for MALDI-TOF analysis was obtained by mixing the matrix, polymer and the cationization agent solution at a 9/1/1 volumeric ratio. Then $1 \mu \mathrm{L}$ of the solution mixture were deposited onto six wells of the sample plate and dried in air at room temperature before being subjected to the MALDI-TOF analysis.

\section{Typical procedure for TREN and $\mathrm{Me}_{6}$-TREN-mediated SET-LRP} in biphasic fluorinated solvent-water mixtures

An organic solvent (TFE or TFP), monomer (MA), water (stock solution containing the ligand (TREN) and $\mathrm{CuBr}_{2}$ ) and an initiator (MBP) were added to a $25 \mathrm{~mL}$ Schlenk tube in the order mentioned. In the case of using $\mathrm{Me}_{6}$-TREN as a ligand, water and the ligand were added separately, following the order: organic solvent, monomer, water, ligand and initiator. The reaction mixture was then deoxygenated by six freezepump-thaw cycles. After these cycles, the Schlenk tube was opened under a positive flow of nitrogen to add the $\mathrm{Cu}(0)$ wire wrapped around a Teflon-coated stir bar. Two more freezepump-thaw cycles were carried out during which the $\mathrm{Cu}(0)$ wrapped in the stir bar was held above the reaction mixture using an external magnet. After that, the Schlenk tube was filled with nitrogen and the reaction mixture was placed in a water bath thermostated at $25^{\circ} \mathrm{C}$. Then, the stir bar wrapped with the $\mathrm{Cu}(0)$ wire was dropped gently into the reaction mixture. The introduction of the $\mathrm{Cu}(0)$ wire defines $t=0$. Samples were taken at different reaction times by purging the side arm of the Schlenk tube with nitrogen for 2 min using a deoxygenated glass syringe and stainless steel needles. The collected samples were dissolved in $\mathrm{CDCl}_{3}$ and quenched by air bubbling. After that, the monomer conversion was measured by ${ }^{1} \mathrm{H}-\mathrm{NMR}$ spectroscopy. In order to determine the molecular weight and polydispersity of the samples, the solvent and the residual monomer were removed under vacuum. Finally the samples were dissolved in THF and passed through a short small basic $\mathrm{Al}_{2} \mathrm{O}_{3}$ chromatographic column to remove any residual copper and subsequently were analyzed by GPC. The resulting PMA was precipitated in cold methanol and dried under vacuum until constant weight to perform chain end analysis by ${ }^{1} \mathrm{H}-\mathrm{NMR}$ spectroscopy, before and after the thioeterification reaction.

\section{General procedure for the chain modification via the "thio-bromo" click reaction}

In a $10 \mathrm{~mL}$ test tube sealed with a rubber septum, thiophenol (0.05 equiv.) and distilled triethylamine ( $\mathrm{NEt}_{3}, 0.05$ equiv.) were added into a solution of the corresponding polymer $(0.01$ equiv.) in acetonitrile $(1 \mathrm{~mL})$ under a nitrogen flow. The reaction mixture was stirred at room temperature for $3 \mathrm{~h}$. Then, the resulting modified PMA was precipitated in cold methanol and washed with methanol several times. The resulting modified polymers were dried under vacuum until constant weight.

\section{Conflicts of interest}

There are no conflicts of interest to declare.

\section{Acknowledgements}

Financial support by the National Science Foundation (DMR-1066116 and DMR-1120901) and P. Roy Vagelos Chair at the University of Pennsylvania is greatly acknowledged. G. L. and M. G. acknowledge support from the Spanish Ministerio de Economía, Industria y Competitividad (MINECO) through projects MAT2014-53652-R and MAT2017-82669-R. G. L. also thanks the Serra Húnter Programme. A. M. was supported by an FPI grant (BES-2015-072662) and a mobility grant (BES-2015-072) from the MINECO. T. L. acknowledges financial support from NanKai University, China. The European Union's Horizon 2020 research and innovation programme under the Marie Sklodowska-Curie grant agreement (No. 642687 to I. B.) is also acknowledged. L. D. thanks the National Natural Science Foundation of China (No 21774107, 21774029).

\section{References}

1 V. Percec, T. Guliashvili, J. S. Ladislaw, A. Wistrand, A. Stjerndahl, M. J. Sienkowska, M. J. Monteiro and S. Sahoo, J. Am. Chem. Soc., 2006, 128, 14156-14165.

2 B. M. Rosen and V. Percec, Chem. Rev., 2009, 109, 50695119.

3 N. Zhang, S. R. Samanta, B. M. Rosen and V. Percec, Chem. Rev., 2014, 114, 5848-5958.

4 G. Lligadas, S. Grama and V. Percec, Biomacromolecules, 2017, 18, 1039-1063.

5 G. Lligadas, S. Grama and V. Percec, Biomacromolecules, 2017, 18, 2981-3008.

6 A. Anastasaki, V. Nikolaou, G. Nurumbetov, P. Wilson, K. Kempe, J. F. Quinn, T. P. Davis, M. R. Whittaker and D. M. Haddleton, Chem. Rev., 2016, 116, 835-877.

7 C. Boyer, N. A. Corrigan, K. Jung, D. Nguyen, T. K. Nguyen, N. N. Adnan, S. Oliver, S. Shanmugam and J. Yeow, Chem. Rev., 2016, 116, 1803-1949.

8 A. Anastasaki, V. Nikolaou and D. M. Haddleton, Polym. Chem., 2016, 7, 1002-1026.

9 N. H. Nguyen, C. Rodriguez-Emmenegger, E. Brynda, Z. Sedlakova and V. Percec, Polym. Chem., 2013, 4, 24242427.

10 X. Leng, N. H. Nguyen, B. van Beusekom, D. A. Wilson and V. Percec, Polym. Chem., 2013, 4, 2995-3004. 
11 Q. Zhang, P. Wilson, Z. Li, R. McHale, J. Godfrey, A. Anastasaki, C. Waldron and D. M. Haddleton, J. Am. Chem. Soc., 2013, 135, 7355-7363.

12 N. H. Nguyen, B. M. Rosen, X. Jiang, S. Fleischmann and V. Percec, J. Polym. Sci., Part A: Polym. Chem., 2009, 47, 5577-5590.

13 N. H. Nguyen, B. M. Rosen and V. Percec, J. Polym. Sci., Part A: Polym. Chem., 2010, 48, 1752-1763.

14 G. Lligadas and V. Percec, J. Polym. Sci., Part A: Polym. Chem., 2007, 45, 4684-4695.

15 N. H. Nguyen, M. E. Levere and V. Percec, J. Polym. Sci., Part A: Polym. Chem., 2012, 50, 860-873.

16 N. H. Nguyen, M. E. Levere, J. Kulis, M. J. Monteiro and V. Percec, Macromolecules, 2012, 45, 4606-4622.

17 S. Fleischmann and V. Percec, J. Polym. Sci., Part A: Polym. Chem., 2010, 48, 2243-2250.

18 G. Lligadas and V. Percec, J. Polym. Sci., Part A: Polym. Chem., 2008, 46, 2745-2754.

19 S. Fleischmann and V. Percec, J. Polym. Sci., Part A: Polym. Chem., 2010, 48, 2236-2242.

20 S. R. Samanta, M. E. Levere and V. Percec, Polym. Chem., 2013, 4, 3212-3224.

21 S. R. Samanta, A. Anastasaki, C. Waldron, D. M. Haddleton and V. Percec, Polym. Chem., 2013, 4, 5555-5562.

22 S. R. Samanta, A. Anastasaki, C. Waldron, D. M. Haddleton and V. Percec, Polym. Chem., 2013, 4, 5563-5569.

23 S. R. Samanta, R. Cai and V. Percec, Polym. Chem., 2014, 5, 5479-5491.

24 S. R. Samanta, H. J. Sun, A. Anastasaki, D. M. Haddleton and V. Percec, Polym. Chem., 2014, 5, 89-95.

25 A. Moreno, D. Garcia, M. Galià, J. C. Ronda, V. Cádiz, G. Lligadas and V. Percec, Biomacromolecules, 2017, 18, 3447-3456.

26 X. Jiang, S. Fleishmann, N. H. Nguyen, B. M. Rosen and V. Percec, J. Polym. Sci., Part A: Polym. Chem., 2009, 47, 5591-5605.

27 S. R. Samanta and V. Percec, Polym. Chem., 2014, 5, 169174.

28 B. M. Rosen, X. Jiang, X. C. J. Wilson, N. H. Nguyen, M. J. Monteiro and V. Percec, J. Polym. Sci., Part A: Polym. Chem., 2009, 47, 5606-5628.

29 B. M. Rosen and V. Percec, J. Polym. Sci., Part A: Polym. Chem., 2007, 45, 4950-4964.

30 X. Jiang, B. M. Rosen and V. Percec, J. Polym. Sci., Part A: Polym. Chem., 2010, 48, 403-409.

31 M. E. Levere, N. H. Nguyen, X. Leng and V. Percec, Polym. Chem., 2013, 4, 1635-1647.

32 N. H. Nguyen and V. Percec, J. Polym. Sci., Part A: Polym. Chem., 2011, 49, 4227-4240.

33 G. Lligadas, B. M. Rosen, M. J. Monteiro and V. Percec, Macromolecules, 2008, 41, 8360-8364.

34 G. Lligadas and V. Percec, J. Polym. Sci., Part A: Polym. Chem., 2008, 46, 6880-6895.

35 M. Enayati, R. B. Smail, S. Grama, R. L. Jezorek, M. J. Monteiro and V. Percec, Polym. Chem., 2016, 7, 72307241.
36 R. B. Smail, R. L. Jezorek, J. Lejnieks, M. Enayati, S. Grama, M. J. Monteiro and V. Percec, Polym. Chem., 2017, 8, 31023123.

37 R. L. Jezorek, M. Enayati, R. B. Smail, J. Lejnieks, S. Grama, M. J. Monteiro and V. Percec, Polym. Chem., 2017, 8, 34053424.

38 M. Enayati, R. L. Jezorek, M. J. Monteiro and V. Percec, Polym. Chem., 2016, 7, 5930-5942.

39 S. Grama, J. Lejnieks, M. Enayati, R. B. Smail, L. Ding, G. Lligadas, M. J. Monteiro and V. Percec, Polym. Chem., 2017, 8, 5865-5874.

40 A. Moreno, S. Grama, T. Liu, M. Galià, G. Lligadas and V. Percec, Polym. Chem., 2017, 8, 7559-7574.

41 M. Enayati, R. L. Jezorek, M. J. Monteiro and V. Percec, Polym. Chem., 2016, 7, 3608-3621.

42 M. Gavrilov, T. J. Zerk, P. V. Bernhardt, V. Percec and M. J. Monteiro, Polym. Chem., 2016, 7, 933-939.

43 M. Gavrilov, Z. Jia, V. Percec and M. J. Monteiro, Polym. Chem., 2016, 7, 4802-4809.

44 V. Percec, A. V. Popov, E. Ramirez-Castillo, M. Monteiro, B. Barboiu, O. Weichold, A. D. Asandei and C. M. Mitchell, J. Am. Chem. Soc., 2002, 124, 4940-4941.

45 V. Percec, A. V. Popov, E. Ramirez-Castillo and O. Weichold, J. Polym. Sci., Part A: Polym. Chem., 2003, 41, 3283-3299.

46 A. D. Asandei and V. Percec, J. Polym. Sci., Part A: Polym. Chem., 2001, 39, 3392-3418.

47 N. H. Nguyen, M. E. Levere and V. Percec, J. Polym. Sci., Part A: Polym. Chem., 2012, 50, 35-46.

48 N. H. Nguyen and V. Percec, J. Polym. Sci., Part A: Polym. Chem., 2010, 48, 5109-5119.

49 M. Enayati, R. L. Jezorek and V. Percec, Polym. Chem., 2016, 7, 4549-4558.

50 A. Anastasaki, C. Waldron, V. Nikolaou, P. Wilson, R. McHale, T. Smith and D. M. Haddleton, Polym. Chem., 2013, 4, 4113-4119.

51 C. Waldron, A. Anastasaki, R. McHale, P. Wilson, Z. Li, T. Smith and D. M. Haddleton, Polym. Chem., 2014, 5, 892-898.

52 C. Boyer, A. Atme, C. Waldron, A. Anastasaki, P. Wilson, P. B. Zetterlund, D. M. Haddleton and M. R. Whittaker, Polym. Chem., 2013, 4, 106-112.

53 A. Simula, G. Nurumbetov, A. Anastasaki, P. Wilson and D. M. Haddleton, Eur. Polym. J., 2015, 62, 294-303.

54 O. Bertrand, P. Wilson, J. A. Burns, G. A. Bell and D. M. Haddleton, Polym. Chem., 2015, 6, 8319-8324.

55 B. M. Rosen, G. Lligadas, C. Hahn and V. Percec, J. Polym. Sci., Part A: Polym. Chem., 2009, 47, 3931-3939.

56 B. M. Rosen, G. Lligadas, C. Hahn and V. Percec, J. Polym. Sci., Part A: Polym. Chem., 2009, 47, 3940-3948.

57 V. Percec and M. Lee, Macromolecules, 1991, 24, 1017-1024.

58 V. Percec and D. Tomazos, Adv. Mater., 1992, 4, 548-561.

59 V. Percec, M. Lee and H. Jonsson, J. Polym. Sci., Part A: Polym. Chem., 1991, 29, 327-337.

60 V. Percec and M. Lee, J. Macromol. Sci., Pure Appl. Chem., 1992, 29, 723-740.

61 V. Percec, J. Heck, M. Lee, G. Ungar and A. Alvarez-Castillo, J. Mater. Chem., 1992, 2, 1033-1039. 
62 V. Percec, D. Schlueter and G. Ungar, Macromolecules, 1997, 30, 645-648.

63 V. Percec, D. Schlueter, G. Ungar, S. Z. D. Cheng and A. Zhang, Macromolecules, 1998, 31, 1745-1762.

64 V. Percec, D. Tomazos and C. Pugh, Macromolecules, 1989, 22, 3259-3267.

65 V. Percec and B. Hahn, Macromolecules, 1989, 22, 1588-1599. 66 V. Percec, J. G. Rudick, M. Peterca, M. Wagner, M. Obata, C. M. Mitchell, W. D. Cho, V. S. K. Balagurusamy and P. A. Heiney, J. Am. Chem. Soc., 2005, 127, 15257-15264.

67 M. N. Holerca, D. Sahoo, M. Peterca, B. E. Partridge, P. A. Heiney and V. Percec, Macromolecules, 2017, 50, 375-385.

68 Z. Zeng, M. F. Wen, G. Ye, X. M. Huo, F. C. Wu, Z. Wang, J. J. Yang, K. Matyjaszewski, Y. X. Lu and J. Chen, Chem. Mater., 2017, 29, 10212-10219.

69 M. Ouchi, T. Terashima and M. Sawamoto, Chem. Rev., 2009, 109, 4963-5050.

70 G. Hattori, Y. Hirai, M. Sawamoto and T. Terashima, Polym. Chem., 2017, 8, 7248-7259.

71 K. A. Andreopoulou, M. Peterca, D. A. Wilson, B. E. Partridge, P. A. Heiney and V. Percec, Macromolecules, 2017, 50, 5271-5284.
72 S. Zhang, Q. Xiao, S. E. Sherman, A. Muncan, A. D. M. Ramos Vicente, Z. Wang, D. A. Hammer, D. Williams, Y. Chen, D. J. Pochan, S. Vértesy, S. André, M. L. Klein, H.-J. Gabius and V. Percec, J. Am. Chem. Soc., 2015, 137, 13334-13344.

73 Q. Xiao, S. Zhang, Z. Wang, S. E. Sherman, R.-O. Moussodia, M. Peterca, A. Muncan, D. R. Williams, D. A. Hammer, S. Vértesy, S. André, H.-J. Gabius, M. L. Klein and V. Percec, Proc. Natl. Acad. Sci. U. S. A., 2016, 113, 1162-1167.

74 V. Percec, D. Schlueter, Y. K. Kwon, J. Blackwell, M. Moeller and P. J. Slangen, Macromolecules, 1995, 28, 8807-8818.

75 Y. K. Kwon, S. N. Chvalun, J. Blackwell, V. Percec and J. A. Heck, Macromolecules, 1995, 28, 1552-1558.

76 Y. K. Kwon, S. Chvalun, A. I. Schneider, J. Blackwell, V. Percec and J. A. Heck, Macromolecules, 1994, 27, 61296132.

77 V. Percec, D. Tomazos, J. Heck, H. Blackwell and G. Ungar, J. Chem. Soc., Perkin Trans. 2, 1994, 31-44.

78 V. Percec, J. A. Heck, D. Tomazos and G. Ungar, J. Chem. Soc., Perkin Trans. 2, 1993, 2381-2388.

79 M. Ciampolini and N. Nardi, Inorg. Chem., 1996, 5, 41-44. 